FÜR BIODIVERSITÄTSFORSCHUNG UND ÖKOLOGIE

- GötTingen Centre for Biodiversity ANd ECOlogy -

\title{
How introgressive hybridization shaped a genus' phylogeny
}

\section{The case of Papio baboons}

\author{
Dissertation zur Erlangung des Doktorgrades der \\ Mathematisch-Naturwissenschaftlichen Fakultäten der \\ Georg-August-Universität Göttingen
}

vorgelegt von

Diplom-Biologin

Christina Keller

aus

Münster

Göttingen, März 2010 
Referentin/Referent: Prof. Dr. Julia Fischer

Korreferentin/Korreferent: Prof. Dr. Eckhard W. Heymann

Tag der mündlichen Prüfung: 10.06.2010 
I dedicate this thesis to Africa ... for everything. 


\section{Table of contents}

$\begin{array}{lr}\text { Summary } & 1\end{array}$

$\begin{array}{ll}\text { Zusammenfassung } & 4\end{array}$

$\begin{array}{ll}\text { General Introduction } & 7\end{array}$

$\begin{array}{ll}\text { Objectives } & 15\end{array}$

Chapter 1 Mitochondrial phylogeography of baboons (Papio spp.) 16

Indication for introgressive hybridization?

Chapter 2 Phylogeography of yellow baboons (Papio cynocephalus)

in East Africa: evaluation of a mitochondrial border

Chapter 3 Introgressive Hybridization in Southern African Baboons

Shapes Patterns of mtDNA Variation

General Discussion

Outlook

Conclusions

References

65

Curriculum Vitae

Publications

74

Acknowledgements 


\section{Summary}

Primates are a diverse order, which exhibits numerous behavioral and morphological traits. To elucidate the evolutionary history of those traits an understanding of the phylogeny of the respective species is essential as homologous traits for instance can only be detected with phylogenetic methods. Although their behavior, ecology and morphology have been studied intensively, the phylogeny and even taxonomy of baboons (genus Papio) is still a matter of debate. Baboons are distributed all over sub-Saharan Africa except for rain forests and dry deserts. Five species are generally acknowledged: Guinea baboon (Papio papio), olive baboon (Papio anubis), hamadryas baboon (Papio hamadryas), yellow baboon (Papio cynocephalus) and chacma baboon (Papio ursinus). In addition the Kinda baboon (Papio kindae) has been suggested to deserve species status. Gene flow between species has been documented repeatedly and complicates the reconstruction of phylogenetic relationships with genetic methods. Apart from ongoing hybridization, ancient hybridization via introgression has been suggested to have played a role in baboon phylogeny. The aims of the present study were to detect evolutionary units within the genus Papio, to elucidate the phylogenetic relationships between them and thereby shed light on the influence of ancient hybridization on the phylogenetic history of baboons. As female philopatry seems to be a plesiomorphic trait in baboons, mitochondrial DNA (mtDNA) as a maternal marker allows inferences on ancient population structures. Combined with morphological information mtDNA can reveal potential ancient hybridization.

Phylogenetic reconstructions identified several well-supported mtDNA-clades. Deep divergences were found between clades within a single species as well as shallow divergences, sometimes even almost identical haplotypes, between different species. The geographical distribution of mtDNA clades does not reflect the distribution of species. As baboon species are defined by their morphology these discordances between mtDNA and morphology lead to paraphylies in all baboon species except Kinda and Guinea baboons.

The phylogeographic patterns suggest a complex evolutionary history with multiple phases of isolation and reconnection of populations. Most likely, the phylogeography of the genus was triggered by climatic changes, namely multiple cycles of expansion and retreat of suitable habitats, mainly savannahs, during Pleistocene glacial and inter-glacial periods. Introgressive hybridization, especially male introgression, during contact phases was indentified to be the most likely reason for discordances between the phylogeography of mtDNA and morphology. During male introgression males of one species invade the range of a neighboring species and hybridize with the resident females. If backcrossing of hybrids with invading males occurs repeatedly over generations, the resident population will be swamped by nuclear DNA (nDNA) of the 
invading species with respective changes in their phenotype while they retain their original mitochondria.

The most striking discordance between morphotype and mtDNA was found in yellow baboons. The deepest split in the phylogenetic tree divides the genus into a northern and southern mtDNA-clade, which diverged $\sim 2.09$ million years ago. Today yellow baboons from northern Tanzania belong to the northern clade while those from southern Tanzania belong to the southern clade. Interestingly, no morphological differences were reported between northern and southern Tanzanian yellow baboons. To investigate this divergence I conducted a dense sample collection in Tanzania to refine the border location between the ranges of these clades and determine the causal origins of its existence. I found the border to run along a central Tanzanian mountain range and further on along the Ruaha and Rufiji River. In contrast to these big rivers, the mountain range does not constitute a dispersal barrier today, but might have been densely forested during wet interglacial periods and yellow baboons normally do not enter deep into dense forests. The mtDNA border might reflect an ancient species border which is not detectable by morphology today as a result of male introgression and nuclear swamping.

My further analyses focused on southern Africa as our earlier results suggest a multi-layered history of hybridization in this area. I aimed to clarify the distribution of different baboon mtDNA clades and to locate possible overlapping zones among them. The phylogenetic reconstruction for southern African baboons revealed mitochondrial paraphyly for the two autochthonous species, chacma and yellow baboons. Again discordance between mtDNA and morphology was probably caused by introgressive hybridization and subsequent nuclear swamping, whereby males of the chacma morphotype from the south invaded the yellow morphotype population further north bringing their nuclear genome and phenotype (morphology) into a population that maintained its yellow baboon mtDNA. As a result grayfooted chacma baboons (Papio ursinus griseipis), a northern subspecies of chacma baboons, show a chacma morphotype but carry mitochondria that are closer related to those of yellow baboons. The two clades with a chacma morphotype overlap in northern Namibia and north-eastern South Africa today.

In conclusion baboons can be divided into several, well-supported mtDNA clades which are often not consistent with species distributions. The identification of evolutionary units might help conservation efforts. My results for instance support the species status of the Kinda baboon, which has not been listed by the IUCN so far. Together with climatic changes, ancient hybridization, especially male introgression, seems to play a major role in baboon phylogeny. These influences most likely affected the evolutionary history of other savannah living species as well, including early hominins. Therefore baboon phylogeny is not only an interesting example for the phylogenetic history of a diverse genus that spread over an entire continent and maintained 
morphological entities despite hybridization, but also a piece in the puzzle of the evolutionary history of Africa. Further details on baboon phylogeny for instance about ongoing hybridization, migration and gene flow direction can only be inferred if nDNA analyses are applied to a complete data set that includes samples from all taxa and all contact zones between them. 


\section{Zusammenfassung}

Primaten stellen eine sehr diverse Ordnung dar. Die verschiedenen Arten entwickelten vielfältige Verhaltensweisen und morphologische Merkmale. Um die Evolution dieser Merkmale zu untersuchen ist ein Verständnis der Phylogenie der entsprechenden Art unerlässlich, da zum Beispiel homologe Merkmale nur mit phylogenetischen Methoden erkannt werden können. Obwohl Paviane zu den am besten untersuchten Primaten gehören, wird über ihre Phylogenie und Taxonomie noch immer debattiert. Die Gattung Papio ist in ganz Afrika verbreitet mit Ausnahme von Regenwaldgebieten und sehr trockenen Wüsten. Fünf Arten werden im Allgemeinen anerkannt: Guineapavian (Papio papio), Anubispavian (Papio anubis), Mantelpavian (Papio hamadryas), Gelber Pavian (Papio cynocephalus) und Bärenpavian (Papio ursinus). Zusätzlich wurde der Kindapavian (Papio kindae) als sechste Art vorgeschlagen. Genfluss zwischen diesen Arten wurde wiederholt nachgewiesen und verkompliziert die Konstruktion phylogenetischer Bäume mit genetischen Methoden. Neben diesen gegenwärtigen Hybridisierungen könnte auch Hybridisierung in der Vergangenheit einen Einfluss auf die Phylogenie der Paviane gehabt haben. Die Ziele dieser Studie waren es evolutionäre Einheiten innerhalb der Gattung Papio zu identifizieren und die phylogenetischen Beziehungen zwischen ihnen zu untersuchen. Hierbei sollte auch der Einfluss von Hybridisierung in der Vergangenheit auf die Phylogenie der Paviane beleuchtet werden. Da bei Pavianen die Männchen abwandern, kann mitochondriale DNA als maternaler Marker Hinweise über alte Populationsstrukturen liefern. Kombiniert mit morphologischen Daten kann mitochondriale DNA auf potentielle, zurückliegende Hybridisierung hinweisen.

Phylogenetische Rekonstruktionen ergaben mehrere gut unterstützte Haplogruppen. Große Unterschiede wurden zwischen Haplogruppen innerhalb einer Art gefunden, ebenso wie teilweise sehr geringe Unterschiede zwischen Haplogruppen verschiedener Arten. Manchmal fanden sich gar verschiedene Arten innerhalb einer Haplogruppe. Die geographische Verbreitung der mitochondrialen Haplogruppen stimmt nicht mit der Verbreitung der Arten überein. Da die Pavianarten anhand ihrer Morphologie bestimmt wurden, führen diese Gegensätze zwischen mitochondrialer DNA und Morphologie zu einer Paraphylie aller Pavianarten mit Ausnahme von Guinea- und Kindapavianen.

Das phylogenetische Muster legt eine komplizierte Evolutionsgeschichte mit mehreren Isolations- und Kontaktphasen nahe. Höchstwahrscheinlich wurde die Gattung hierbei von klimatischen Veränderungen beeinflusst, z.B. von zyklischen Ausdehnungen und Verkleinerungen ihres Habitates, hauptsächlich Savannen, während der glazialen und inter-glazialen Phasen des Pleistozäns. Introgressive Hybridisierung, insbesondere die männliche Introgression, während der Kontaktphasen wurde als wahrscheinlicher Grund für die Unterschiede zwischen der Verbreitung von mitochondrialen Haplogruppen und 
Morphotypen identifiziert. Bei der männlichen Introgression wandern Männchen einer Art in das Gebiet einer anderen Art ein und pflanzen sich mit den ansässigen Weibchen fort. Wenn die Einwanderung über Generationen weiterhin nur einseitig von Männchen einer Art erfolgt, wird die andere Art das nukleäre Genom der Einwanderer annehmen, was entsprechende Änderungen des Morphotyps nach sich zieht. Hierbei bleibt das originale Mitochondrium unberührt.

Der auffälligste Gegensatz zwischen Morphotyp und mitochondrialer DNA trat bei den Gelben Pavianen auf. Der tiefste phylogenetische Einschnitt der Gattung teilt die Paviane in eine nördliche und eine südliche Haplogruppe, welche sich vor 2.09 Millionen Jahren trennten. Heutige Gelbe Paviane aus dem nördlichen Tansania gehören der nördlichen Haplogruppe an, während ihre Artgenossen aus dem südlichen Tansania der südlichen Haplogruppe angehören. Interessanterweise wurden bisher keine morphologischen Unterschiede zwischen den Pavianen aus dem nördlichen und südlichen Tansania gefunden. Um dieses Phänomen zu untersuchen, führte ich eine ausgiebige Sammlung von Kotproben in Tansania durch. Hierdurch wollte ich die genaue Lage der Grenze zwischen den Haplogruppen klären und dadurch Einblicke in mögliche Ursachen für ihre Existenz erlangen. Meine Ergebnisse legen nahe, dass die Grenze zwischen den Haplogruppen entlang eines Zentral-tansanischen Gebirges verläuft und dann dem Flusslauf des Ruaha und des Rufiji folgt. Im Gegensatz zu den Flüssen stellt der erwähnte Gebirgszug heute keine Migrationsbarriere für Paviane dar. Allerdings könnte er während feuchter Klimaperioden von Regenwald bedeckt gewesen sein, welcher von Gelben Pavianen gemieden wird. Die Haplogruppen-Grenze ist möglicherweise ein Überbleibsel einer alten Artgrenze, welche heute anhand von Morphologie nicht mehr erkennbar ist, da männliche Introgression die Morphotypen, nicht jedoch die Mitochondrien verändert hat.

Meine weiteren Analysen bezogen sich schwerpunktmäßig auf das südliche Afrika, da frühere Ergebnisse eine interessante Hybridisierungsgeschichte in diesem Gebiet vermuten ließen. Mein Ziel war die Klärung der Verbreitung verschiedener Haplogruppen und der Lage von möglichen Überlappungsgebieten. Die phylogenetische Rekonstruktion für die Paviane des südlichen Afrikas zeigte mitochondriale Paraphylie für beide dort vorkommenden Arten, Bären- und Gelber Pavian. Auch hier wurden die Gegensätze zwischen Morphologie und mitochondrialer DNA wahrscheinlich durch introgressive Hybridisierung verursacht. Hierbei sind vermutlich Männchen vom Chacma Morphotyp aus dem Süden in Populationen mit Gelbem Morphotyp eingewandert. Dadurch brachten die Chacma-Männchen ihren Morphotyp und ihr nukleäres Genom in die Gelbe Pavianpopulation, welche ihr ursprüngliches Mitochondrium jedoch bewahrte. Als Folge dieses Prozesses entstanden die sogenannten graufüßigen Chacmapaviane (P.u. griseipis), eine nördliche Unterart des Chacmapavians. Diese haben heute einen Chacma Morphotyp, aber tragen ein Mitochondrium welches näher mit dem der Gelben Paviane 
verwandt ist. Beide Chacma Haplogruppen überlappen heute im nördlichen Namibia und im Nord-östlichen Südafrika.

Zusammenfassend können Paviane in mehrere, gut unterstützte mitochondriale Haplogruppen eingeteilt werden, welche jedoch oft nicht mit Artgrenzen übereinstimmen. Die Identifizierung solcher evolutionärer Einheiten kann möglicherweise den Artenschutz unterstützen. So unterstützen meine Ergebnisse zum Beispiel den Status des Kindapavians als eigene Art, welche bisher nicht von der IUCN gelistet wurde. Zusammen mit klimatischen Veränderungen, spielten vergangene Hybridisierungen vermutlich eine große Rolle in der Stammesgeschichte der Paviane. Dieselben klimatischen Einflüsse könnte auch die Evolution anderer Arten, welche dasselbe Habiat bevorzugten (z.B. frühe Hominide), beeinflusst haben. Daher stellt die Phylogenie der Paviane nicht nur ein interessantes Beispiel für die Stammesgeschichte einer diversen Gattung dar, welche über einen gesamten Kontinent verbreitet ist und ihre morphologischen Einheiten trotz Hybridisierung bewahrt hat. Vielmehr ist die Phylogenie der Paviane auch ein Stück des Puzzles der evolutionären Geschichte Afrikas. Weitere Details der Phylogenie der Paviane, zum Beispiel über gegenwärtige Hybridisierung sowie Wander- und Genflussrichtungen, können nur durch Analysen nukleärer DNA erforscht werden. Diese Analysen sollten auf einen kompletten Datensatz, der alle Taxa sowie ihre Kontaktbereiche abdeckt, angewendet werden. 


\section{General Introduction}

With over 300 species primates are among the most diverse mammal orders. They exhibit a great array of behavioral and morphological traits (Smuts et al. 1987, Geissmann 2003). Among mammals primates show the largest diversity of social systems (Kappeler \& van Schaik 2002). To understand the evolution of those traits, an understanding of the evolutionary relatedness between the species is obligatory. Homologous traits for instance can only be recognized on the basis of phylogeny.

Phylogeny is the study of evolutionary relatedness among various taxa (Futuyama 2007). It involves the succession of splitting events in phylogenetic trees or networks. Consequently, a sound phylogeny of a species is important for studies of several if not all biological disciplines, especially those studies containing comparative approaches. Asking for the adaptive value of any trait one necessarily needs to know if this trait has been acquired by the respective species as an adaptation to their environment or if it is an ancestral trait that evolved under different ecological conditions. A trait shown today might be as well maladaptive or neutral under present conditions and just travelled on through the history of the species as a relict that has not yet been eliminated by selection (e.g. goosebumps in modern humans).

An example how insufficient phylogenetic knowledge can led to erroneous results is the study of Waser (1982), who compared the loud calls of baboons and mangabeys and interpreted the observed similarities and differences according to the phylogenetic knowledge inferred from morphological data, which was that mangabeys and baboons are sister genera (Kuhn 1967, Szalay \& Delson 1979). Molecular studies, however, revealed a diphyly of mangabeys (Cronin \& Sarich 1976) which have been split into two genera, Cercocebus and Lophocebus (Groves 1978). Lophocebus is the sister taxon of Papio and Theropithecus while Cercocebus is the sister taxon of Mandrillus (Disotell 1994). The diphyly of Mangabeys was also supported by detailed morphological analyses later on (Gilbert 2007) Two of the mangabey species studied by Waser belong to the genus Lophocebus and one to the genus Cercocebus. Waser's conclusions would therefore probably look quite different today.

A positive example how phylogeny can explain present phenomena is the study of Van Ngoc (2010) on the vocal and genetic diversity in crested gibbons. He found that genetic similarity is reflected in the acoustic structure of gibbon calls. Species could be distinguished not only by genetic but also acoustic analysis, which provides a useful tool for conservation efforts as acoustic data are often easier to get than genetic samples.

Van Ngoc's study as well as this study are parts of a large-scale project that was initiated at the German Primate Center in 2007. The objective of this Primate-Biodiversity project was the identification of evolutionary units, the reconstruction of the phylogenetic relationships between them and the investigating of underlying mechanisms 
that influenced the emergence of primate diversity. This knowledge was meant not only to help understanding primate evolution but also to support conservation efforts. Five separate projects investigated different primate genera representative for different continents and primate radiations. My study focused on the genus Papio as represent of the African Old World monkeys and a phylogenetic radiation that started about 2 mya (Newman et al. 2004, Wildman et al. 2004).

Baboons of the genus Papio offer an intriguing subject for phylogenetic studies due to their wide distribution, ecological flexibility and variability in morphology. Furthermore baboons are among the best studied primates. Their behavior (for a review see Barrett $\&$ Henzi 2005, Barrett 2009, Cheney \& Seyfarth 2007) and physiology (for a review see VandeBerg \& Cheng 1986) have been studied intensively. Comparative studies investigated ecology (Hill \& Dunbar 2002, Hill et al. 2000, Dunbar 1994, Kamilar 2006), socio-ecology (Barrett \& Henzi 2005) and morphology (Frost et al. 2003) across taxa and agreed that there is much to be gained from an accurate phylogeny of the genus. Nevertheless the phylogeny as well as the number of taxa within the genus is not well understood (for reviews see Hill 1970, Jolly 1993, Groves 2001).

Baboons are distributed all over sub-Saharan Africa, excluding the west and central African rainforests. They even colonized parts of Arabia. During times with a more suitable climate, baboons ranged far into the Sahara Desert, where small relict populations in the Air and Tibesti Mountains can still be found (Kingdon 1997). They constitute clusters of allopatric populations with five traditionally recognized phenotypically distinct species.

The five generally acknowledged baboon species are the Guinea baboon (Papio papio) from west Africa, the olive baboon ( $P$. anubis) from the northern savannah belt, the hamadryas baboon ( $P$. hamadryas) occupying North-east Africa and south-western Arabia, the yellow baboon ( $P$. cynocephalus) ranging in the East African coastal lowlands and the chacma baboon (P. ursinus) living in most parts of southern Africa (Groves 2001, Zinner et al. in press; Fig. I). The taxonomic level of several subspecies of these five species is debated. Of these the elevation of the Kinda baboon (Papio c. kindae) to species level received the most support (Jolly 1993, Frost et al. 1993). The Kinda baboon, mainly inhabiting Angola and central Zambia, was rarely studied, but Jolly $(1993,2001)$ and Frost et al. (2003) suggested elevating it to a full species due to the morphological deviation from other yellow baboons (Frost et al. 2003) with which it was previously lumped (Groves 2001, Kingdon 1997). It is considerable smaller in size and Kinda infants show a white coat (Jolly \& Phillips-Conroy 2005, Phillips-Conroy et al. 2009).

A survey of the literature concerning the taxonomic status within Papio revealed the following: The taxonomic status of the main morphotypes is debated, sometimes they 


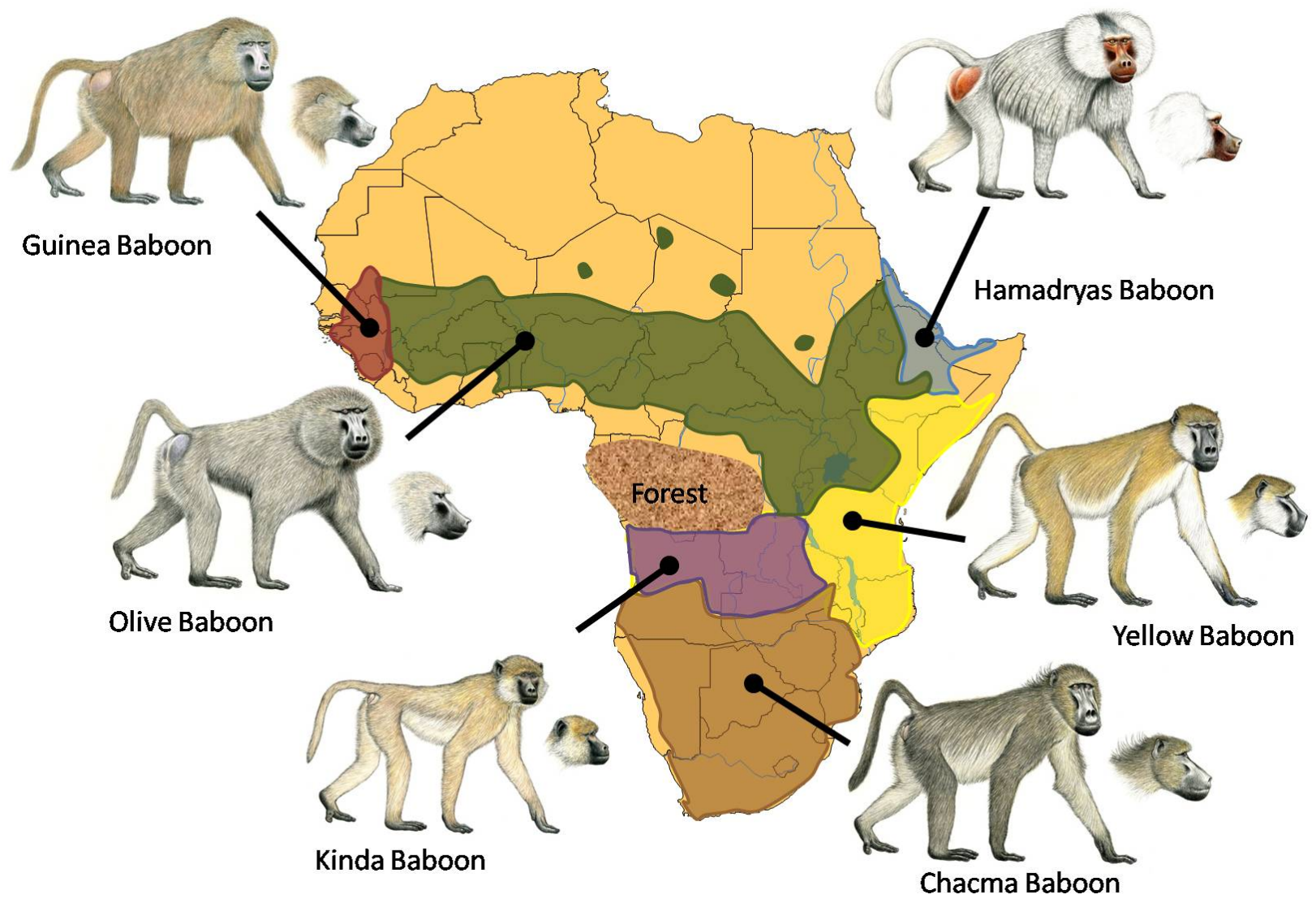

Figure I: Pictures and distributions of the six baboon species, adapted from Kingdon 1997. Drawings by Stephen Nash (not to scale).

are called species (Groves 2001, Grubb 2003) and sometimes (allopatric) subspecies (Frost et al. 2003, Jolly 1993) of a superspecies (Papio hamadryas). The numerous different species concepts distinguish species using different criteria like for instance reproductive isolation (Dobzhansky 1937, Mayr 1969), diagnosability (Cracraft 1983), monophyly (de Queiroz \& Donoghue 1988), evolutionary significance (Simpson 1961), ecology (van Valen 1976) or morphology (Cronquist 1978). Due to ecological similarity (Kamilar 2006) and repeated recordings of fertile hybrids between most Papio taxa in captivity (Hill 1970) and in the wild (e.g. hamadryas x olive baboons: Nagel 1973, PhillipsConroy \& Jolly 1986; yellow x olive baboons: Samuels \& Altmann 1986, Tung et al. 2008, Alberts \& Altman 2001) baboons can be considered to be one species. But at least the five major morphotypes retain their morphological distinctiveness despite hybridization. Therefore they can also be considered to be full species. The same might be true for several "subspecies" whose morphological distinctiveness and possible separate course in evolution have yet to be investigated. Taxonomic opinion depends on the preferred species concept (for discussion see Groves (2001) and Jolly (1993)). To solve the taxonomic problem is far beyond the scope of this study. For sake of convenience I will adopt the view of many baboon researchers (e.g. Burrell 2008; Jolly 1993) and experts on primate taxonomy (Groves 2001) and accept all five traditionally recognized morphotypes 
as species. Additionally, I accept the Kinda baboon as full species following Burrell (2008), Frost et al. (1993) and Jolly (1993). As suggested by Jolly (1997-1998), I will use the common names of the species which are not under debate.

As in many species the phylogeny of the genus Papio was triggered by biogeographic events, such as climatic and geographic changes. The availability of suitable habitats limits the genus' range. Although baboons have adapted to a variety of habitats from desert over savannah to open woodland and even swamps (Kamilar 2006, Jolly 1993), they do normally not occur in dense rain forest or dry deserts. Stretches of unsuitable habitat e.g. water bodies, high mountain ranges, forest belts or dry areas without access to open water can separate baboon populations. Climate changes influenced the extension or retraction of the baboons' habitats (Hamilton \& Taylor 1991). Two to three million years ago (mya) a climatic change modified the ecological conditions on the African continent (deMenocal 2004). As the continent became cooler and drier the equatorial rain forest that spanned Africa from east to west along the equator like a belt, shrank and opened up savannah corridors (Hamilton \& Taylor 1991) which allowed an exchange of savannah living species from south to north and vice versa. Subsequently several cycles of warm/wet and cold/dry phases which were contemporary with northern cycles of interglacial and glacial periods probably led to multiple extensions and retractions of the forest belt within the last $2 \mathrm{my}$ (Hamilton \& Taylor 1991). The forest belt seems to have constituted a barrier for savannah and open woodland species for considerable time spans (Arctander et al. 1999, Grau Nersting \& Arctander 2001, Muwanika et al. 2003).These climatic and ecological changes probably caused a complex phylogeny of the genus Papio.

The radiation within the genus started relatively recently, about 2 my (Newman et al. 2004, Wildman et al. 2004) and speciation seems to be "in motion". Frequent hybridization has been observed in East African contact zones between olive and hamadryas baboons in Awash National Park, Ethiopia (Bergman \& Beehner 2004, Nagel 1973, Phillips-Conroy \& Jolly 1986) and olive and yellow baboons in Amboseli National Park, Kenya (Alberts \& Altmann 2001). Hybridization is assumed within the contact zone of olive and Guinea baboons in Mauretania, Mali, Guinea and Ivory Coast (Galat-Luong et al. 2006, Tahiri- Zagrët 1976). It has even been suggested that olive baboons are a species of hybrid origin, as well as the yellow ibeanus morphotype from Kenya and northern Tanzania that exhibits some olive baboon-like features (Jolly 1993). No indication of selection against hybrids has been reported. In contrast, there might actually be advantages for hybrid males, such as having a more attractive phenotype to females (Nystrom 1992, Woolley-Barker 1999) or an earlier age of dispersal than one or either of the parent-taxa (Tung et al. 2008). Hybridization is likely to occur wherever two neighboring baboon species come into contact. However, the locations of most of these contact zones and the extent to which hybridization occurs in the wild remains unclear. 
There have been many attempts to disentangle the phylogeny of baboons. Behavioral and morphological differences set the hamadryas baboon apart from the rest (Jolly 1965). The "hamadryas vs. the rest" model suggests that all other taxa should be lumped under the name "savannah baboons" (Papio cynocephalus). The same traits that set apart hamadryas baboons can, to a lesser degree, be found in Guinea baboons (Jolly 1993) which would suggest that these two are sister taxa to the exclusion of the other "savannah baboons". Skull morphology on the other hand shows similarities among southern baboons (yellow, chacma and Kinda baboons) and among northern baboons (olive, Guinea and hamadryas baboons), respectively, but dissimilarities between northern and southern (Frost et al. 2003). This would suggest a north-south division of the genus. As the fossil record points towards a southern or south-eastern origin of the genus (Benefit 1999, Gilbert 2008, McKee 1992), the southern group would be considered ancestral in this case.

In contrast, first molecular studies using blood proteins (Williams-Blangero et al. 1990) and short mtDNA sequences (Disotell 1992) found an ancestral position of the Guinea baboon. In 2004 two studies based on longer mtDNA sequences found the chacma baboon to be ancestral (Newman et al. 2004, Wildman et al. 2004). The ancestral position of the southern African chacma baboon would fit better to the southern African origin of baboons as inferred from the fossils (McKee 1992). Both Wildman et al. and Newman et al. state that the unusually close relationships between taxa (olive and hamadryas: Wildman et al. 2004, olive and yellow baboons: Newman et al. 2004) are possibly the result of ancient hybridization between the species.

While contemporary hybridization can be detected by direct observations of interspecific mating and the resulting intermediate morphotypes, the detection of ancient hybridization requires phylogenetic methods. Ancient hybridization can be detected by the comparison between the phylogenies of different genetic markers or between those and the taxonomy and biogeography based on morphometric data. Natural hybridization can have different effects on population structure. When two closely related species come into contact and hybridize, several scenarios are possible. If there is selection against hybrids the hybrid zone will stay relatively narrow with few backcrosses and low gene flow between species. If hybrids have a selective advantage they can expand their range and even replace one or both of the parent species. This would result in hybrid speciation. If both sexes from both parent species ( $A$ and $B$ ) contribute to the hybrid population one speaks of bidirectional hybridization. If, for example, only one sex of species A hybridizes with species B and not vice versa one speaks of unidirectional hybridization.

If females of species $A$ disperse and hybridize with males from species $B$ two scenarios are possible. If no backcrossing with the invading species $A$ takes place the nuclear genome of invaded species B would barely change but would absorb mtDNA from 
species A. This process is called mitochondrial capture. If on the other hand hybrids backcross with more and more invading females of species $A$ over generations, nuclear swamping can be the result. Here we have the case of female introgression. This scenario can be assumed if a population carries the X-chromosomal, autosomal and mitochondrial DNA from the invading species but the $Y$-chromosome of the invaded one.

If males are the dispersing sex and hybridize with females from a neighboring species $B$ the resulting hybrids have two possibilities for backcrossing. If they backcross intensively over generations with males of the invading species A (what can e.g. happen if the invading males have an advantage over the resident ones) the population will eventually carry the nuclear genome from the species $A$, while the mtDNA would still remain that of the invaded species $B$. This process can be called nuclear swamping via male introgression. Figure II shows a scheme of this process. If hybrids backcross with the invaded species $B$ the resulting population would keep their $\mathrm{X}$-chromosomal, autosomal and mtDNA, but would capture the Y-chromosome from the invading species ( $Y$ chromosome capture).

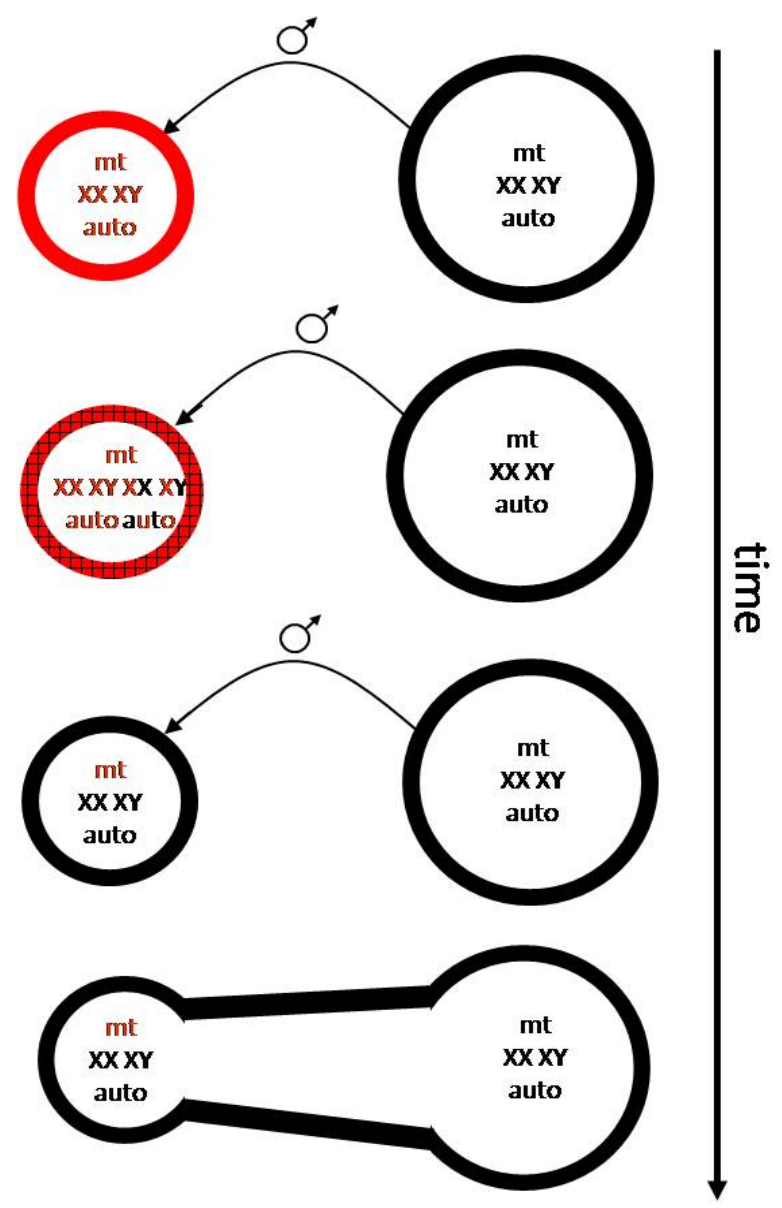

Figure II: Scheme of male introgression and subsequent nuclear swamping from population A to population B over several generations. Adapted from Zinner et al (in press.). 
Of course these scenarios are extreme cases with only one sex dispersing and exclusive backcrossing of hybrids with only one parent species. In nature intermediate scenarios (e.g. fusions of groups from different species) are likely but a general trend to one of the described processes has been detected in several species including primates (hybrid speciation: Macaca arctoides Tosi et al. 2003; mitochondrial capture: Rungwecebus kipunji Zinner et al. 2009; male introgression: M. mulatta, M. fascicularis Bonhomme et al. 2009).

For baboons two of these processes have been suggested to explain the discordance between mtDNA phylogeny and morphotype variation that was detected close to the hamadryas $x$ olive baboon hybrid zone. Hapke et al. (2001) suggested female mediated gene flow via transfer of olive or hybrid females into hamadryas populations. This would lead to a spread of olive-like mitochondria in hamadryas groups. Wildman et al. (2004) included more samples from pure olive populations in his analysis and found that the mitochondria that Hapke et al. had thought to be of olive origin were actually originally from hamadryas baboons which suggests male mediated gene flow in the other direction (from olive to hamadryas baboons). This example shows how important sampling over the whole range of a species can be.

Depending on the respective research question mtDNA markers can have advantages or disadvantages. MtDNA has been used intensively in many phylogenetic studies (e.g. otters: Centron et al. 2008, dolphins: Kingston et al. 2009, langurs: Roos et al. 2008, turtles: Spinks et al. 2009) including studies on baboons (Disotell 1992, Hapke et al. 2001, Newman et al. 2004, Wildman et al. 2004, Winney et al. 2004). One advantage of mtDNA is its high fixation rate in comparison to nuclear DNA (nDNA) which makes it possible to investigate events that happened in close succession before nDNA could come to fixation. In addition mtDNA is haploid and only transmitted by females, which reduces the effective population size and thereby the fixation time of mtDNA (Avise 2004). Another advantage is the large number of mtDNA copies within a cell, which makes mtDNA easy to obtain even from low quality material, like feces. Characteristic for mtDNA are its solely maternal inheritance (but see Avise 2000, 2004) and its function as a single locus. Single locus studies are unable to rule out sorting failures of ancestral polymorphisms (incomplete lineage sorting) while maternal markers alone are unable to detect hybridization as mtDNA is not recombining and male introgression does not leave any traces in a set of maternal markers. Therefore mtDNA is unaffected by male migration events and can potentially reflect older underlying population structures in female philopatric species. Ideally mtDNA should be combined with autosomal or/and Ychromosomal markers to detect both, ancient population structures and more recent migration events of both sexes. If this is not possible morphology can be used to infer on the nuclear genome of a species, in the way that a similar morphology hints to a similar, closer related nuclear genome. 
In my study I used mtDNA markers to reconstruct a baboon phylogeny and compared the distribution of mtDNA clades to the ranges of morphotypes. The first goal was to explore the mtDNA phylogeny of all baboon taxa and to thereby get a complete, if not detailed picture of the distribution of mtDNA variation. Therefore I joined an ongoing project on this topic led by D. Zinner, who had already collected numerous genetic samples of baboons from all over Africa and parts of Arabia. The data set contained all five traditionally recognized morphotypes over much of their range. One species was missing in the data set though, the Kinda baboon. In Zambia the ranges of three baboon species meet, the Kinda baboon, the yellow baboon and the grayfooted baboon that is considered to be a subspecies of the chacma baboon (Hill 1970). So far there was nothing known about hybridization in this area. Therefore I started my project by collecting genetic material in Zambia.

After filling this sampling gap I added my data to the data set of D. Zinner (Chapter 1). We aimed to reconstruct a mtDNA phylogeny of Papio, estimate divergence times and propose a dispersal scenario in relation to climatic and geological changes during the Pleistocene. Furthermore, by comparing the distribution of mtDNA clades and morphotypes we expected to identify potential areas for ongoing and ancient hybridization.

Although a general mtDNA phylogeography of baboons was proposed in this initial study (Chapter 1 ), details on regional pattern were still not understood. One interesting result of Chapter 1 was that the genus Papio showed a deep split into a northern and a southern mtDNA-clade. The border between the ranges of these clades was assumed to be somewhere in Tanzania. Here it seemed to divide the yellow baboons into a northern and southern part. I therefore aimed to detect the exact location of the genetic border between the northern and southern mtDNA clade in Tanzania (Chapter 2). Considering historic, biogeographic events I hoped to elucidate possible reasons for the existence and location of the mtDNA border.

Furthermore, especially in southern Africa the number of baboon subspecies, their phylogenetic relationships and the level of hybridization were unknown (Jolly 1993). This was partly due to the difficulty of reconstructing phylogenetic relationships among closely related forms that probably interbred and partly due to the problem of obtaining samples across the broad geographical range of baboons. These two problems are interlinked as incomplete taxon sampling complicates the statistical reconstruction of phylogenetic relationships immensely (Spinks et al. 2009) and there are more than 10 baboon taxa described from southern Africa (Hill 1970).

Three baboon species occur in southern Africa (Fig. I), the yellow, the Kinda and the chacma baboon. Two further taxa might merit species or subspecies status, two variants of the chacma baboon: the grayfooted baboon (P. u. griseipes) from Mozambique, Botswana, Zimbabwe and southern Zambia that is described to be bigger than other chacmas and 
has a divergent pelage-color (Jolly 1993) and the Ruacana chacma baboon (P. u. ruacana) that is also called Kalahari chacma and inhabits Namibia and southern Angola and is described to be darker and stockier than other chacmas (Jolly 1993). Hill (1970) described even more morphological variants of yellow and chacma baboons. The morphological diversity in southern Africa seems to be much higher than in the northern part of the continent (see number of subspecies in Hill 1970). This may be due to the longer time span southern African baboons might have had to evolve as the origin of the genus is believed to be in southern Africa (Benefit 1999, McKee 1992), a fact that made this part of Africa even more interesting in terms of baboon phylogeny. For all these reasons I choose to focus on the southern part of the African continent and to concentrate my effort in obtaining a full geographic record, meaning to include all taxa into my data set (see Chapter 3). Thereby I hoped to refine the phylogeography of southern African baboons and to elucidate possible ancient hybridization between species. Although hybridization has not been observed in southern Africa so far, the results of Chapter 1 hinted towards possible ancient hybridization between yellow and chacma baboons.

\section{Objectives}

The objective of my study was to reconstruct the phylogeography of the genus Papio based on mtDNA and to elucidate the factors that influenced it, especially hybridization. I focus on the eastern and southern African baboon taxa and aim to refine the geographical resolution of the distribution map of baboon mtDNA clades with a focus on contact zones between taxa. I discuss my results in light of the biogeographic and climatic history of the African continent. Finally, I describe a scenario for the history of the genus Papio that best explains my results. My results allow conclusions on general evolutionary mechanisms that affected African savannah and open woodland species including our own ancestors. Furthermore, the identification of evolutionary units that deserve protection might help to support conservation efforts. 
Chapter 1

Mitochondrial phylogeography of baboons (Papio spp.)

Indication for introgressive hybridization?

doi:10.1186/1471-2148-9-83 


\section{Chapter 2}

Phylogeography of yellow baboons (Papio cynocephalus) in East Africa: evaluation of a mitochondrial border 


\title{
Phylogeography of yellow baboons (Papio cynocephalus) in East Africa: evaluation of a mitochondrial border
}

\author{
CHRISTINA KELLER ${ }^{*}$, CHRISTIAN ROOS ${ }^{\S}$, DIETMAR ZINNER ${ }^{*}$ \\ ${ }^{*}$ Cognitive Ethology, German Primate Center, Kellnerweg 4, 37077 Goettingen, Germany, ${ }^{\S}$ Gene Bank of \\ Primates and Primate Genetics, German Primate Center, Kellnerweg 4, 37077 Goettingen, Germany
}

\begin{abstract}
:
Discordances between mtDNA phylogeny and morphology have been reported repeatedly within the genus Papio. One of the most striking discordances was observed in yellow baboons (Papio cynocephalus). The deepest split in the mtDNA phylogeny of baboons divides Tanzanian yellow baboons into a northern and a southern clade. No morphological distinction between baboons north and south of the geographical mtDNA border was described. Genetic material from Tanzania is scarce so far and the exact location of the mtDNA border is therefore unknown. We performed a dense sample collection in the area where the border was suggested to be. We were able to locate the mtDNA border in central Tanzania. The fine geographic resolution allowed us to suggest that the border runs along the Kipengere range towards the Rubeho Mountains and further on along the Ruaha and Rufiji River. The tops of these mountain ranges are still densely forested and forests might have stretched out between the mountains during periods of favourable climatic conditions. Tropical rain forest is a dispersal barrier for yellow baboons and might therefore have separated baboon populations for certain time periods. Male introgression is the most likely explanation for the discordance between mtDNA and morphotype that we observe today. We assume that southern yellow males invaded the range of another species living north of the border, maybe pre-hamadryas baboons. Today's similar morphotype of baboons north and south of the mtDNA border would consequently be the result of nuclear swamping.
\end{abstract}

Key words: mtDNA, phylogeny, introgression, nuclear swamping, Tanzania

\section{Introduction}

Geographical patterns of mitochondrial DNA (mtDNA) variation do not always coincide with taxonomic or morphological patterns (bats: Berthier et al. 2006, squirrels: Good et al. 2003). In species with female philopatry the maternally inherited mtDNA has the potential to reflect former isolation in secondary contact zones. This is of great importance if unidirectional male migration followed by repeated extensive backcrossing might lead to a homogenous morphotype and nuclear genome (nuclear swamping). As a result, formerly isolated populations might nowadays look alike, as differences, which had evolved during isolation, might be masked by male migration. MtDNA is unaffected by male migration. Especially if 
mtDNA phylogenies are compared to those based on nuclear DNA (nDNA) and/or morphology, inferences about previous hybridization events in secondary contact zones of female philopatric species (Avise 2004) can be made.

On the African continent distribution patterns and phylogenetic relationships in several savannah species have been explained with historic vicariance (roan antelope (Hippotragus equinus): Alpers et al. 2004, wildebeest (Connochaetes taurinus): Arctander et al. 1999, giraffe (Giraffa camelopardalis): Brown et al. 2007, hartebeest (Alcelaphus buselaphus): Flagstad et al. 2001, warthog (Phacochoerus africanus): Muwanika et al. 2003, spotted hyenas (Crocuta crocuta): Rohland et al. 2005). All these species show a phylogenetic split into a northern and southern population. The equatorial forest belt has been used to explain this pattern. This belt of tropical rain forest spanned the African continent almost continuously from west to east along the equator. There is some evidence that the forest underwent repeated cycles of extension and retraction during the last 2 million years (my), following glacial cycles of dry/cool and wet/warm conditions (deMenocal 2004, Hamilton 1988, Hewitt 2000). Nevertheless a general trend towards forest retraction was suggested for the whole period (deMenocal 1995). This suggests that the African forest belt was probably larger and completely closed for at least parts of the Quaternary and thus, constituted a barrier for dispersal of savannah species.

Today there is only one gap in the closed rain forest, in Tanzania in East Africa. This is an interesting area for the phylogenetic studies of savannah species as they might use this corridor as migration route. The corridor is formed by miombe forest which is only marginal habitat for savannah species. Nevertheless many savannah species are tolerant to open woodland, the landscape found throughout many parts of Tanzania (own observations).
In the genus Papio discordances between phylogenies based on mtDNA and taxonomy/morphology have been reported (Burrell 2008, Keller et al. 2010, Sithaldeen et al. 2009, Zinner et al. 2009,). Of the five species, recognized by most baboon researchers (yellow, Guinea, olive, hamadryas and chacma), female philopatry is the norm in at least yellow, chacma and olive baboons (Altmann \& Altmann 1970, Cheney \& Seyfarth 1976, Dunbar 1988). The Kinda baboon that we acknowledge as a sixth species was barely studied and nothing is known about its dispersal pattern. Baboons comprise several mtDNA clades that do not reflect species or even subspecies borders (Zinner et al. 2009). The deepest split in the phylogenetic tree of baboons divides the genus into two major mtDNA clades, a northern and a southern one (Burrell 2008, Zinner et al. 2009). The geographical border between these clades is comprised by central African rain forest and the clades come into contact in central Tanzania (Zinner et al. 2009) where the border between the two major mtDNA clades divides the range of yellow baboons into a northern and southern part. Within the Tanzanian yellow baboons no morphological differences have been reported, not even at subspecies level. Hill (1970) reports only one taxon in Tanzania, $P$. c. cynocephalus. The neighbouring yellow baboon taxa $P$. $C$. ibeanus from Kenya and Somalia and P. c. strepitus from Malawi are all distributed further away from the presumed mtDNA border location (Hill 1970).

Although baboon mtDNA phylogeny has been studied intensely during the last years only few yellow baboon sample from Tanzania have been analysed (Kilwa: Burrell 2008, Mikumi NP: Wildmann et al. 2004, Lake Rukwa region: Zinner et al. 2009). Introgression has been proposed before to be an important mechanism that affected the phylogenetic history of baboons (Keller et al. 2010, Zinner et al. 2009). To fill the geographic sampling gap in Tanzania we focussed our research effort on yellow baboons in Tanzania and 
performed a dense fecal sample collection to shed light on the phylogenetic history of baboons in this area. Our aim was to locate the geographic position of the border between the southern and northern mtDNA clade in Tanzania and to determine the causal origins of its existence.

\section{Methods}

\section{Sample collection}

We collected and analyzed 27 fecal samples from free ranging baboons in Tanzania and added 12 sequences deposited in GenBank. In total, we used one sequence each from 39 sites in Tanzania, Kenya, Zambia, Malawi and Somalia (Fig. 1). Fresh samples were preserved in $75 \%$ ethanol and samples found dry were stored on silica gel. We stored the samples at ambient temperature for up to six months before further processing. The geographic coordinates of the sampling sites were recorded by GPS. Additionally, one sequence each from Theropithecus gelada, Macaca sylvanus and Lophocebus aterrinus was included in the analysis.

Sampled baboon populations were assigned to the morphologically distinct taxon yellow baboon (P. cynocephalus) using Kingdon (1997) and Jolly (1993). An accurate further differentiation of more subtle morphotypes such as Ibean yellow baboon was impossible as the animals were not habituated and could not be observed closely. Sample localities (geographic coordinates in decimal degrees) and haplotype designations are given in Table 1. GeneBank accession numbers will be added after submission to the journal.

\section{DNA extraction, amplification and}

\section{sequencing}

We extracted DNA from fecal material using the QiAamp DNA Stool Mini Kit from Qiagen. To prevent contamination, laboratory procedures followed described standard protocols (Karanth et al. 2005, Osterholz et al. 2008, Roos et al. 2008). In detail, DNA extraction, PCR and sequencing was performed in separate laboratories. We performed all PCR reactions with negative (HPLC-purified water) controls.

We amplified and sequenced the complete mitochondrial cytochrome $b$ gene (1140 bp) using primers and Polymerase Chain reaction (PCR) conditions as described in Zinner et al. (2009). PCR products were checked on $1 \%$ agarose gels and purified using Montage Microcon PCR Centrifugal Filter Devices (Milipore) or gel purification. We sequenced both strands on an ABI 3130xl sequencer using the same forward and reverse primers applied for the amplification and the BigDye Terminator Cycle Sequencing Kit (Applied Biosystems).

\section{Statistical analyses}

One sample per location was analyzed. 39 $P$. cynocephalus sequences and one sequence each from T. gelada, $M$. sylvanus and $L$. aterrinus were edited, aligned using BioEdit v7.5.0.2 (Hall 1999), and checked by eye. The optimal nucleotide substitution model was chosen using the Akaike Information Criterion (AIC) as implemented in MODELTEST v3.7 (Posada \& Crandall 1998). 1,000 bootstrap replications were performed. All sequences were translated into amino acid sequences to check for unexpected stop codons.

We removed identical sequences for the tree construction analyses. For Neighbor-joining (NJ) and Maximum Likelihood (ML) analyses, we employed the optimal nucleotide substitution model as selected with MODELTEST v3.7. The NJ analysis was conducted using PAUP* v4.0b10 (Swofford 2002). Robustness of relationships was tested with 1,000 bootstrap replications. We conducted the ML reconstruction using a genetic algorithm approach implemented in GARLI v0.96b8 (Zwickl 2006). In GARLI only the model specifications settings were 
Table 1

Sample localities (geographic coordinates in decimal degrees) and haplogroup designations.

\begin{tabular}{|c|c|c|c|c|c|}
\hline ID & Latitude & Longitude & site code & Location & Haplogroup \\
\hline 151 & -15.750000 & 34.916670 & Mic & Michiru Mountains Cons. Area 2 & SY2 \\
\hline 288 & -15.950000 & 35.516670 & Mu2 & Mulanje Mt.2 & SY3 \\
\hline 404 & -7.582970 & 32.155170 & Ruk & Lake Rukwa & SY2 \\
\hline 409 & -13.268400 & 31.637930 & LuS & South Luangwa NP & SY1 \\
\hline 507 & 2.420830 & 45.433330 & Web & Webi Shebelli & NY1 \\
\hline 529 & -4.320000 & 39.550000 & Dia & Diani Beach & NY2 \\
\hline 537 & -2.290000 & 37.390000 & $\mathrm{Amb}$ & Amboseli & NY1 \\
\hline 570 & -12.457800 & 32.145500 & Lua & Luambe NP & SY1 \\
\hline 600 & -11.860580 & 32.433560 & Chf & Chifunde & SY2 \\
\hline 611 & -12.663360 & 32.124900 & LS1 & between Luambe, Mfuwe & SY1 \\
\hline 615 & -12.750000 & 32.092030 & LS2 & between Luambe, Mfuwe & SY1 \\
\hline 617 & -13.101280 & 31.778360 & Mfu & Mfuwe & SY1 \\
\hline 944 & -7.234800 & 37.209760 & Mik & Mikumi NP & NY1 \\
\hline 951 & -7.265960 & 37.189050 & Mk1 & Mikumi NP & NY1 \\
\hline 954 & -7.355220 & 37.061270 & Mk2 & Mikumi NP & NY1 \\
\hline 960 & -7.346510 & 37.164630 & Mk4 & Mikumi NP & NY1 \\
\hline 961 & -6.626530 & 37.583420 & Mrg & north of Morogoro & NY1 \\
\hline 963 & -6.625850 & 37.578970 & Mgr & north of Morogoro & NY1 \\
\hline 970 & -6.059920 & 35.575630 & Dod & $30 \mathrm{~km}$ west of Dodoma & NY1 \\
\hline 978 & -7.130160 & 35.988290 & $\mathrm{sDm}$ & Dodoma->Iringa & NY1 \\
\hline 983 & -7.338540 & 35.731750 & nIg & Dodoma->Iringa & NY1 \\
\hline 988 & -7.373040 & 35.743250 & nIn & Dodoma->Iringa & NY1 \\
\hline 994 & -8.909260 & 34.190860 & Kma & Kamani & SY3 \\
\hline 1003 & -9.909430 & 35.507960 & Son & $100 \mathrm{~km}$ north of Songea & SY3 \\
\hline 1009 & -9.983470 & 35.627800 & nSo & north of Songea & SY3 \\
\hline 1010 & -10.713460 & 35.266430 & wSo & west of Songea & SY3 \\
\hline 1028 & -11.085410 & 37.432730 & Che & Chem-Chem (south of Tunduru) & SY3 \\
\hline 1031 & -11.260540 & 37.513630 & sTu & Amani (south of Tunduru) & SY3 \\
\hline 1057 & -10.869150 & 38.600930 & wMs & west of Masasi & SY3 \\
\hline 1063 & -10.594700 & 38.988380 & Chw & Chiwata & SY3 \\
\hline 1071 & -10.108550 & 39.657510 & Min & Mingoyo & SY3 \\
\hline 1073 & -10.495060 & 39.992970 & Nan & Nanguruwe & SY3 \\
\hline 1074 & -10.595220 & 40.135280 & Kit & north of Kitaya & SY3 \\
\hline 1080 & -10.410070 & 39.978460 & Dih & Dihimbo & SY3 \\
\hline 1096 & -8.637510 & 39.307550 & Sin & east of Sinza & SY3 \\
\hline 1106 & -6.635740 & 38.132030 & eMw & east of Mwindu & NY1 \\
\hline 1110 & -6.248470 & 38.387860 & Wam & Wami River & NY1 \\
\hline 1115 & -5.054710 & 39.028470 & Ami & Amboni River & NY2 \\
\hline 1128 & -5.387070 & 38.651020 & Sgr & Segera & NY1 \\
\hline
\end{tabular}


adjusted to the chosen $\operatorname{TrN}+\mathrm{G}$ model $($ ratematrix $=($ abaaba $))$. State frequencies were estimated. We left all other settings at their default value. Ten replicates were run to verify consistency in log likelihood $(\operatorname{lnL})$ scores and tree topologies. ML bootstrap percentages were estimated in GARLI by performing 1,000 pseudoreplicate runs. We calculated a majority-rule consensus tree using PAUP* v4.0b10 in order to obtain bootstrap percentages. Bayesian analyses were conducted with MrBayes v3.2-cvs (Huelsenbeck et al. 2001, Ronquist \& Huelsenbeck 2003). We used four Monte Carlo Markov chains (MCMC) with a temperature of 0.05 . Two repetitions were run for 10 million generations with tree and parameter sampling occurring every 100 generations. We assumed flat priors for the model parameters including the proportion of invariable sites and the gamma shape parameter of rate variation among sites. Characters were partitioned into first, second and third codon positions. The HKY (nst=2) model was used for the first and second codon positions, and the GTR (nst=6) model for the third codon position. The models were chosen by MODELTEST v3.7. Rate heterogeneity and base frequencies were unlinked across codon positions $((1+2), 3)$. The first $10 \%$ of samples were discarded as burnin. We tested the adequacy of this burnin and convergence of all parameters by visual inspection of the trace of the parameters across generations using AWTY (Nylander et al. 2008; Wilgenbusch et al. 2004); Posterior probabilities (PP) for each split and a phylogram with mean branch lengths were calculated from the posterior density of trees using MrBayes v3.2-cvs.

\section{Results}

Among the 39 individual baboon sequences, we detected 31 unique haplotypes. Throughout the gene no indel positions were detected. The translation into amino acid sequences revealed no unexpected stop codons. Furthermore, our
PCR products were amplified easily and with high concentrations. As nuclear loci of this length are difficult to amplify in high concentrations from fecal samples stored dry or in ethanol (Burrell 2008) we assume that our data set is free of nuclear pseudogenes (numts). Excluding the outgroup T. gelada, we found 1013 constant sites $\left(356,361,296\right.$ for the $1^{\text {st }}, 2^{\text {nd }}$ and $3^{\text {rd }}$ codon position, respectively), 23 uninformative sites $\left(6,3,14\right.$ for the $1^{\text {st }}, 2^{\text {nd }}$ and $3^{\text {rd }}$ codon position, respectively), and 104 parsimony-informative sites $(18,16$, 70 for the $1^{\text {st }}, 2^{\text {nd }}$ and $3^{\text {rd }}$ codon position, respectively) among the $1140 \mathrm{bp}$ of the sequenced part of the cyt $b$ gene.

All phylogenetic analyses (NJ, ML, Bayesian) showed similar topologies with a deep split between northern and southern yellow baboons (Fig. 2). We found two well supported clades within the northern yellow baboons (NY1, NY2) and three clades within the southern yellow baboons (SY1, SY2, SY3).

\section{Discussion}

With our dense sampling in the expected border region between the ranges of the northern and southern mtDNA clades we were able to support earlier findings that mtDNA phylogeny of yellow baboons shows a remarkable heterogeneity. An obvious explanation for the existence of two deeply divergent clades is past vicariance caused by natural dispersal barriers like large rivers or dense tropical forests. The border between the two clades crosses Tanzania from west to east (Fig. 1). The habitat around the border is more or less continuously occupied by baboons today (according to information from locals and own observations). One possible former barrier might have been dense tropical forests occupying the Tanzanian mountain ranges. The former dispersal barrier therefore might have been constituted of tropical forest in the Kipengere range and further on towards the Rubeho mountains (Fig. 1). The tops of these ranges are still densely forested and 


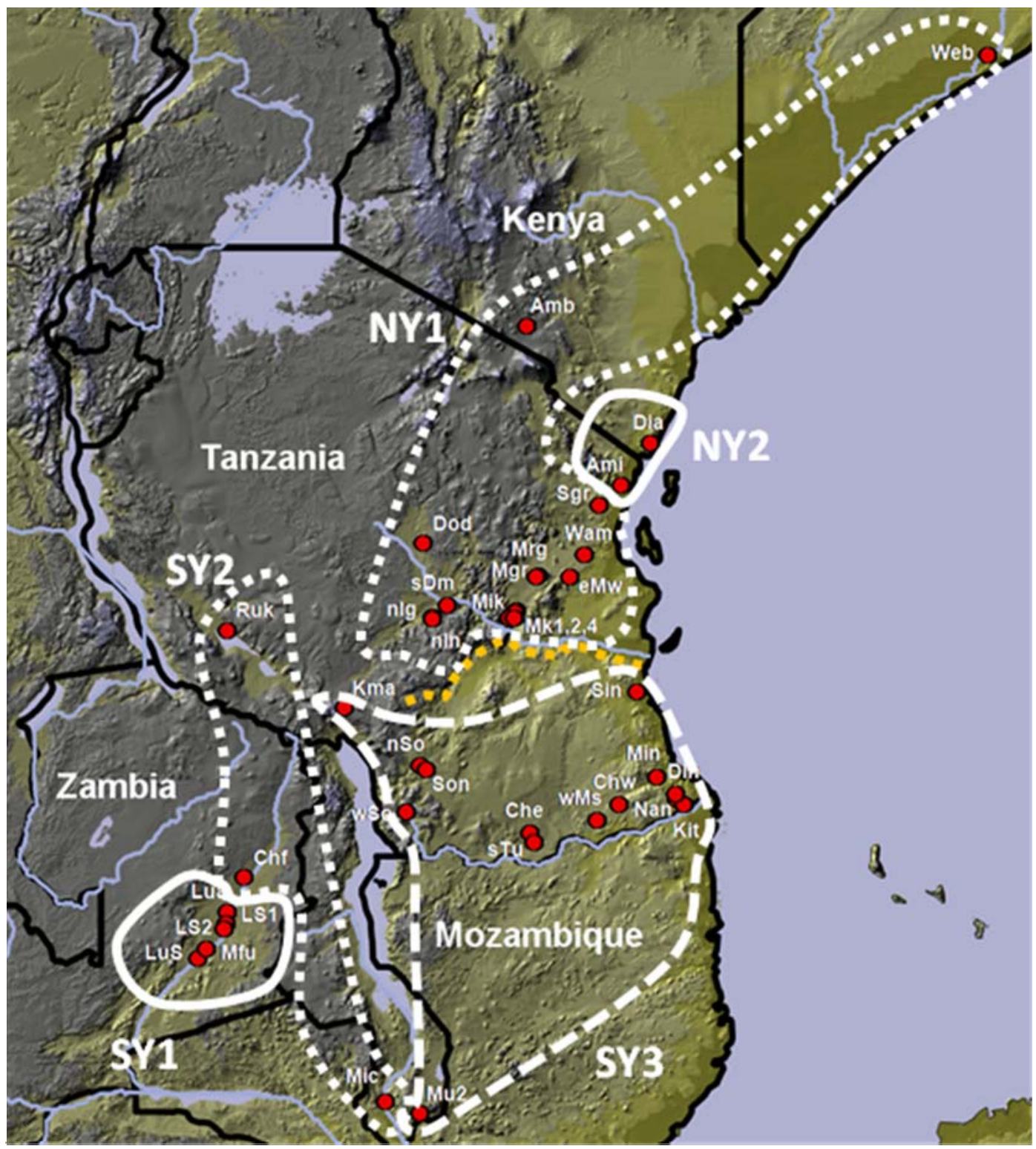

Figure 1

Geographic distribution of mtDNA clades in eastern Africa (SY1, SY2, SY3, NY1, NY2). Sampling sites are indicated by red dots and labelled with site codes according to Table 1 . The yellow dashed line indicates the supposed border between the northern and southern mtDNA clade.

the forest might have stretched between the mountain tops to form a continuous barrier for baboon dispersal. This route is supposed to be a dispersal route for forest species (Hamilton 1988) and might therefore act as a barrier to savannah species. At the north-western tip of the Selous Game Reserve the proposed border meets the Great Ruaha River and might therefore have gone on along the Great Ruaha and further east along the Rufiji River, which has been described as dispersal barrier for mammals before (Kingdon \& Howell 1993). The border might have separated two distinct species or subspecies that evolved in isolation for a significant period of time. Today the tropical rain forest in Tanzania is confined to the mountain tops (Wasser \& Lovett 1993) which most likely allows unlimited contact between baboon populations.

As the climate was not stable during the last 2 my but rather underwent cycles of hot/wet and cold/dry weather conditions 


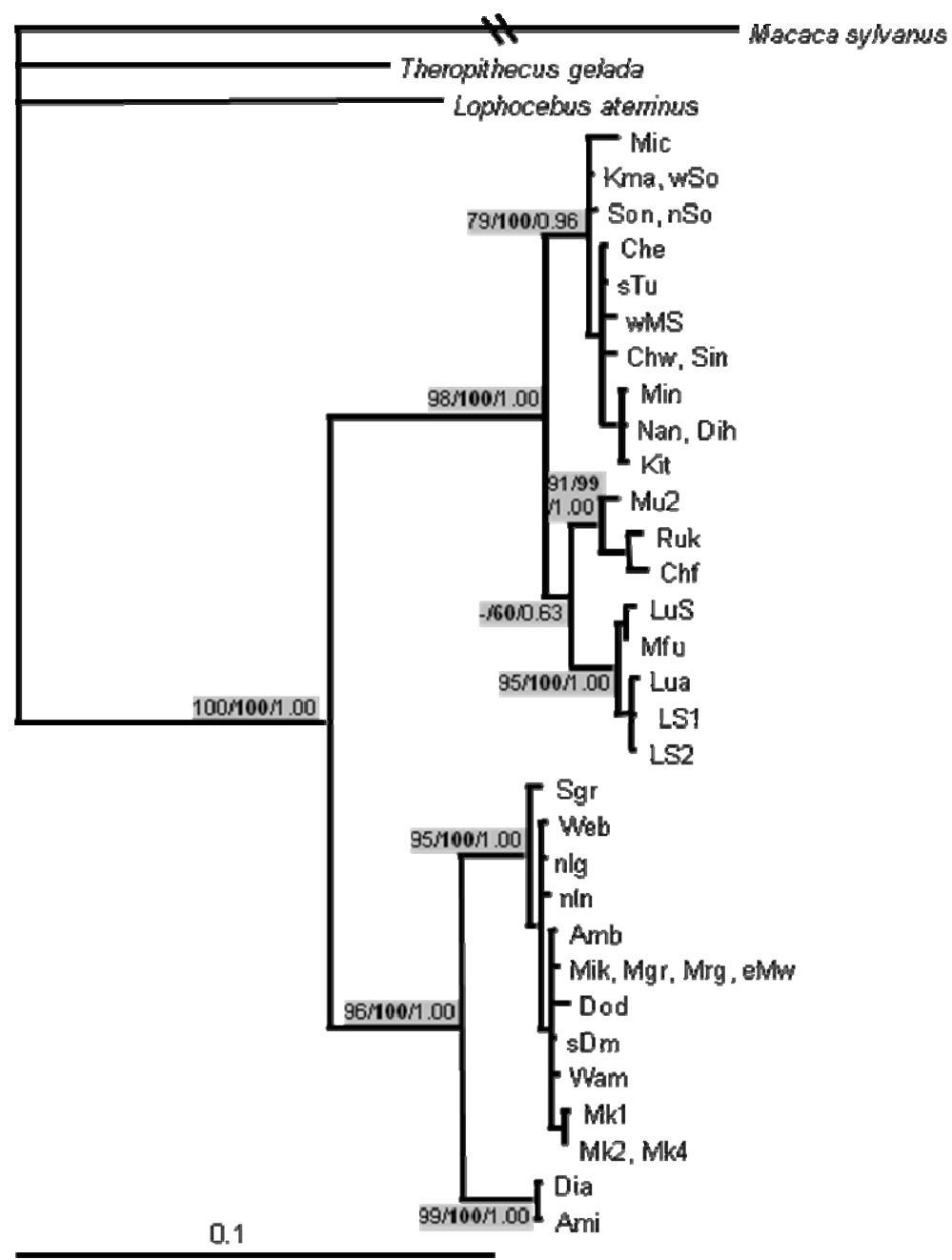

Figure 2

Phylogram based on ML analysis and the cytochrom b gene (1140bp). Bootstrap or posterior probability values are given at selected nodes (first: ML [bold], second: NJ, third: Bayesian). Dashes indicate values below 50\% or 0.50 .

(deMenocal 2004), multiple separation and reconnection events are likely. The substructure of the northern and southern yellow baboons might be a result of this multi-layered history. In the southern yellow baboon clade Lake Malawi seems to separate haplogroup SY2 and SY3. SY2 might represent $P$. c. strepitus as described in Hill (1970). Haplogroup SY1 represents the Luangwa yellow baboons (also called $P$. u. jubilaeus) that we described in an earlier study (Keller et al. 2010). Among the northern baboons we find two haplogroups, NY1 and NY2. The latter were described as coastal yellow baboons by Zinner et al. (2009). There is no obvious reason why NY2 should be or have been separated from NY1. Furthermore the closest relatives of NY2 are olive baboons from Ethiopia (unpublished data). Nuclear data from Ethiopian baboons would hopefully shed light on this confusing phenomenon that might be due to incomplete lineage sorting.

The similar or even same morphotype of all Tanzanian baboons today is probably a result of male introgression. The question remains if this introgression took place from northern to southern yellow baboons or the other way around. In an earlier study (Keller et al. 2010) we proposed a northward introgression of southern yellow baboons by the Cape chacma baboons which resulted in the formation of grayfooted chacma baboons which exhibit a chacma morphotype but carry a "yellowlike" mtDNA. If the southern yellow baboons themselves are a result of introgression we must assume that another baboon taxon whose morphotype has been 
replaced after chacma and yellow baboon introgressions is the source of the grayfooted chacma and southern yellow baboon mitochondria. This is not the most parsimonious explanation. Therefore we consider it much more likely that the "original" yellow baboons are today represented by the southern yellow baboons.

The question remains who the ancestors of the northern yellow baboons' mtDNA were and what they might have looked like before they had been introgressed. The fossil record gives no answer to this question. Possible candidates are progenitors of hamadryas baboons, who have been suspected before of having had a much greater range than they have today (Zinner at al. 2009, in press), and might be the source of the present northern yellow baboon mitochondria. Another possibility is that an eastern baboon population, whose morphotype is unknown and extinct nowadays, occupied the range of present northern yellow baboons and was morphologically replaced by the southern yellow baboons, leaving behind their mitochondria. This population would have been closely related to hamadryas baboons.

\section{Conclusions}

In conclusion our study suggests that the border between the two major mtDNA clades in the genus Papio runs between the Kipengere range and the Rubeho Mountains and further on along the Great Ruaha and Rufiji River in Tanzania. As other explanations seem unlikely we believe that male introgression caused the discordance between mtDNA and morphology in Tanzania. Introgression has also been suggested for other parts of the baboon's range where morphology and mtDNA do not seem to fit (Keller et al. 2010, Zinner et al. 2009). Nuclear data from all these regions would help to underpin these suggestions and allow highly interesting comparisons of different contact zones between baboon taxa.

\section{Acknowledgements}

We are thankful to Julius W. Nyahongo, the University of Dodoma, TAWIRI and COSTECH for their help during sample collection in Tanzania. For funding we thank the WGL. We are also grateful to R. Liedigk for his help in the lab.

\section{References}

Alpers D, Van Vuuren B, Arctander P, Robinson T (2004) Population genetics of the roan antelope (Hippotragus equinus) with suggestions for conservation. Molecular Ecology, 13, 1771-1784.

Altmann SA, Altmann J (1970) Baboon Ecology, African Field Research. Chicago: University of Chicago Press.

Arctander P, Johansen C, Coutellec-Vreto MA (1999) Phylogeography of three closely related African bovids (tribe Alcelaphini). Molecular Biology and Evolution, 16, 1724-1739.

Avise J (2004) Molecular Markers, Natural History, and Evolution. Sunderland, MA: Sinauer Associates.

Berthier P, Excoffier L, Ruedi M (2006) Recurrent replacement of mtDNA and cryptic hybridization between two sibling bat species Myotis myotis and Myotis blythii. Proceedings of the Royal Society of London B, 273, 3101-3123.

Brown D, Brenneman R, Koepfli KP, Pollinger J, Mila B, Georgiadis N, Louis E, Grether G, Jacobs D, Wayne R (2007) Extensive population genetic structure in the giraffe. BMC Evolutionary Biology, 5, 57.

Burrell AS (2008) Phylogenetics and Population Genetics of Central African Baboons. PhD thesis, New York University, New York.

Cheney-Seyfarth D (1976) Social development of immature baboons. Cambridge: Cambridge University Press.

deMenocal PB (2004) African climate change and faunal evolution during the 
Pliocene-Pleistocene. Earth and Planetary Science Letters, 220, 3-24.

deMenocal PB (1995). Plio-Pleistocene African Climate. Science, 270, 53-59.

Dunbar RIM (1988) Primate Social systemy. Oxford: Cornell University Press.

Flagstad O, Syvertsen P, Stenseth N, Jakobsen K (2001) Environmental change and rates of evolution: the complex phylogeographic pattern within the hartebeest complex as related to climatic variation. Proceedings of the Royal Society of London B, 268, 667677.

Good J, DemboskiI J, Nagorsen D, Sullivan J (2003) Phylogeography and introgressive hybridization: chipmunks (genus Tamias) in the northern Rocky Mountains. Evolution, 57, 1900-1916.

Hall TA (1999) BioEdit: a user-friendly biological sequence alignment editor and analysis program for Windows 95/98/NT. Nucleic Acid Symposium Series, 41, 95-98.

Hamilton A (1988) Guenon evolution and forest history. A primate radiation: evolutionary biology of the African guenons (ed. Gautier-Hion A., Bourliere F., Gautier J.-P. and Kingdon J.). pp 1335 Cambridge: Cambridge University Press.

Hewitt G (2000) The genetic legacy of the Quaternary ice ages. Nature, 405, 907913.

Hill WCO (1970) Primates: Comparative Anatomy and Taxonomy VIII Cynopithecinae: Papio, Mandrillus, Theropithecus. Edinburgh: Edinburgh University Press.

Huelsenbeck JP, Ronquist F, Nielsen R, Bollback JP (2001) Bayesian inference of phylogeny and its impact on evolutionary biology. Science, 294, 2310-2314.

Jolly CJ (1993) Species, subspecies and baboon systematics. In: Species, Species Concepts, and Primate Evolution (ed. Kimbel WH, Martin LB). pp 67-107. New York: Plenum Press.
Karanth KP, Delefosse T, Rakotosamimanana B, Parsons TJ, Yoder AD (2005) Ancient DNA from giant extinct lemurs confirms single origin of Malagasy primates. Proceedings of the National Academy of Sciences of the USA, 102, 5090-5095.

Keller C, Roos C, Groeneveld L, Fischer J Zinner D (2010) Introgressive Hybridization in Southern African Baboons Shapes Patterns of mtDNA Variation. American Journal of Physical Anthropology, published online.

Kingdon J (1997) The Kingdon Field Guide to African Mammals London: Academic Press.

Kingdon J, Howell K (1993) Mammals in the forests of eastern Africa. In: Biogeography and ecology of the rain forests in Eastern Africa, (ed.Wasser S., Lovett J.), Cambridge: Cambridge University Press, pp. 229-241.

Muwanika VB, Nyakaana S, Siegismund HR and Arctander P (2003) Phylogeography and population structure of the common warthog (Phacochoerus africanus) inferred from variation in mitochondrial DNA sequences and microsatellite loci. Heredity, 91, 361-372.

Nylander JA, Wilgenbusch JC, Warren DL, Swofford DL (2008) AWTY (Are we there yet?): a system for graphical exploration of MCMC convergence in Bayesian phylogenetics. Bioinformatics, 24, 581-583.

Osterholz M, Walter L, Roos C (2008) Phylogenetic position of the langur genera Semnopithecus and Trachypithecus among Asian colobines, and genus affiliations of their species groups. BMC Evolutionary Biology, 8, e58.

Posada D, Crandall KA (1998) Modeltest: testing the model of DNA substitution. Bioinformatics, 14, 817-818.

Rohland N, Pollack JL, Nagel D, Beauval C, Airvaux J, Pääbo S, Hofreiter $M$ (2005) The Population History of 
Extant and Extinct Hyenas. Molecular Biology and Evolution, 22, 2435-2443.

Roos C, Nadler T, Walter L (2008) Mitochondrial phylogeny, taxonomy and biogeography of the silvered langur species group (Trachypithecus cristatus). Molecular Phylogenetics and Evolution, 47, 629-636.

Ronquist F, Huelsenbeck JP (2003) MrBayes 3: Bayesian phylogenetic inference under mixed models. Bioinformatics, 19, 1572-1574.

Sithaldeen R, Bishop JM, Ackermann RR (2009) Mitochondrial DNA analysis reveals Plio-Pleistocene diversification within the chacma baboon. Molecuar Phylogenetics and Evolution, 53, 10421048.

Swofford D (2002) PAUP* Phylogenetic analysis using parsimony (*and other methods). Vers. 4. Sunderland, MA: Sinauer Associates.

Wasser S, Lovett J (1993) Introduction to the biogeography and ecology of the rain forests in eastern Africa. In: Biogeography and ecology of the rain forests in Eastern Africa (ed. Wasser S, Lovett J), Cambridge: Cambridge University Press, pp. 3-7.

Wildman D, Bergman T, al-Aghbari A, Sterner K, Newman T, Phillips-Conroy J, Jolly C Disotell T (2004) Mitochondrial evidence for the origin of hamadryas baboons. Molecular Phylogeny and Evolution, 32, 287-296.

Wilgenbusch JC, Warren DL, Swofford DL (2004) AWTY: A system for graphical exploration of MCMC convergence in Bayesian phylogenetic inference. http://ceb.csit.fsu.edu/awty.

Zinner D, Groeneveld LF, Keller C, Roos C (2009) Mitochondrial phylogeography of baboons (Papio spp.) - Indication for introgressive hybridization? BMC Evolutionary Biology, 9, 83.

Zinner D, Buba U, Nash S, Roos C (in press) Pan-African voyagers. The Phylogeography of baboons. In: Primates of Gashaka. Socio-ecology and Conservation in Nigeria's
Biodiversity Hotspot (ed. Sommer V, Ross C), Series: Developments in Primatology: Progress and Prospects. New York: Springer.

Zwickl DJ (2006) Genetic Algorithm Approaches for the Phylogenetic Analysis of Large Biological Sequence Data Sets under the Maximum Likelihood Criterion. PhD thesis, The University of Texas at Austin. 
Chapter 3

Introgressive Hybridization in Southern African Baboons Shapes Patterns of mtDNA Variation

Doi:10.1002/ajpa.21209 


\section{General Discussion}

Combined in one picture the results of D. Zinner and me reveal a detailed distribution map of different mtDNA clades (Fig. III). The most striking result was the incongruence between the distributions of morphotypes and the distribution of mtDNA clades inferred from phylogenetic reconstructions. This results in mtDNA paraphyly for most baboon species, which are traditionally defined by their morphology. Only Kinda and Guinea baboons show a concordance of morphotype and mtDNA. Both constitute well supported clades (Fig.III). In all other species (hamadryas, yellow, olive and chacma baboons) discordances between the distributions of mtDNA clades and morphotypes were observed.

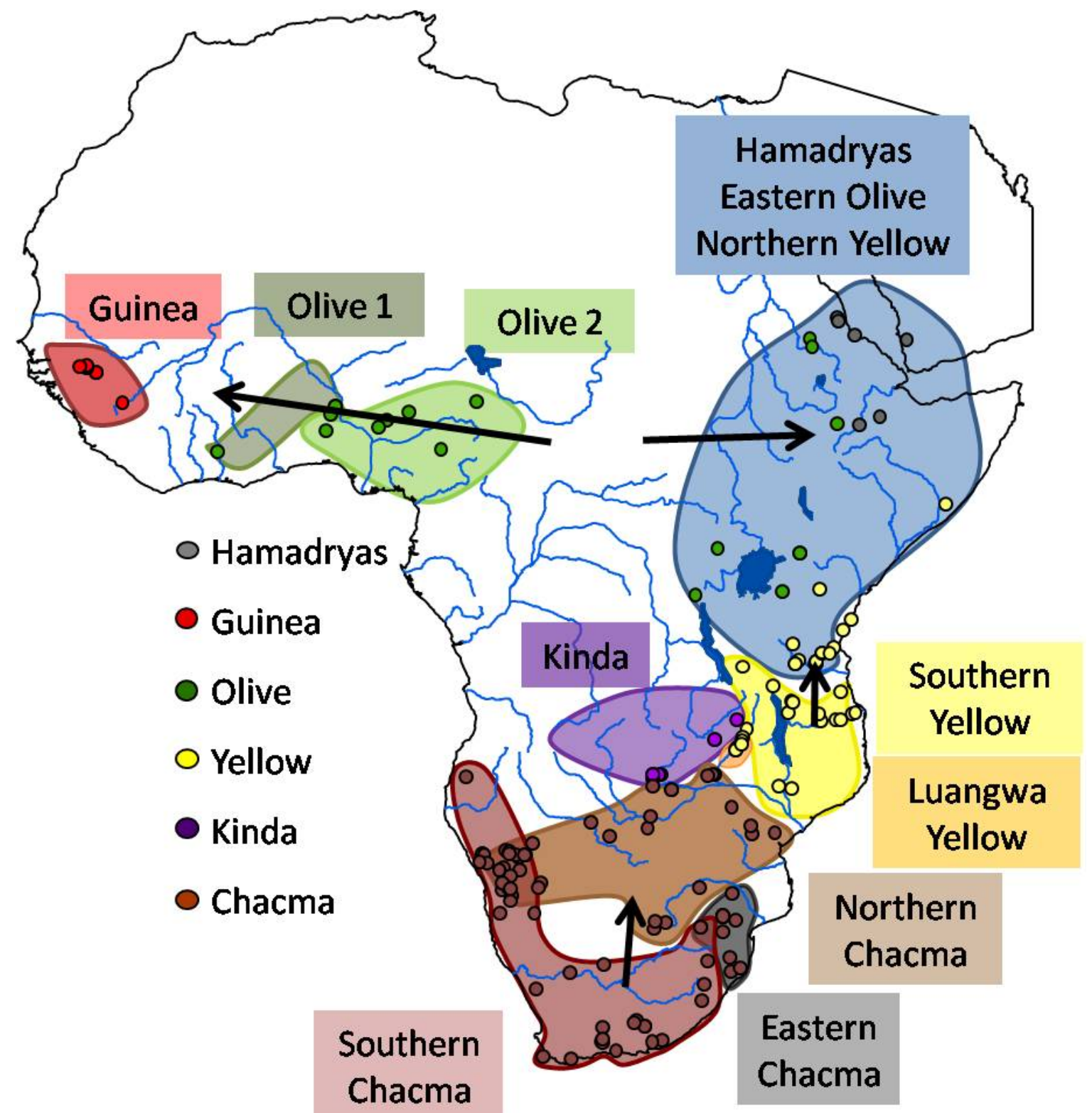

Figure III: Sampling locations and mtDNA (cyt b) clade distribution of the genus Papio. Shaded areas indicate approximate clade distributions. As indicated in the Figure dot colors designate the species. Arrows indicate supposed main migration directions. 
Discordances between mtDNA and morphology can have several causes. The general assumption that similarity reflects common ancestry can be undermined by convergent evolution, leading to homoplasy. Convergent evolution in DNA sequences is, however, highly unlikely due to the high number of variable sites. One problem with the use of mtDNA is the possible existence of nuclear pseudogenes (nuclear mitochondrial DNA or numt). A numt is created if the mitochondrial genome integrates itself partially or even completely into the nuclear genome of the host cell. Here it evolves independently from the original $\mathrm{mt}$ genome, adopting the slower mutation rate of the nuclear genome. Although mutation rates differ, numt sequences will still remain similar to real $\mathrm{mt}$ sequences and hence, misamplifications can happen during the PCR process. A mix of mtDNA and numt sequences would then lead to erroneous results when calculating phylogenetic trees. As there are many more mitochondria than nuclei in a cell the number of mtDNA copies far exceeds the one of nuclear genome. Nuclear genes are considerably harder to amplify, especially from low quality material like feces. Even if high quality material is available the concentrations of amplified DNA from the nucleus will still be magnitudes lower than those amplified from the numerous mitochondria. If, as happened in my study, DNA is amplified in high concentrations from low quality material a contamination with pseudogenes is highly unlikely (Thalmann et al. 2004). To check whether numts might have influenced the sequence data, every unusual sequence was sequenced twice. No indications for incongruence were found in the overlapping region of the two cytochrome b parts that were amplified separately. Additionally, all sequences were translated into protein sequences and no unexpected stop codons were found. Consequently I am confident that the data set is free of numts.

A problem that always arises in single locus studies is incomplete lineage sorting. Incomplete lineage sorting means that ancestral polymorphic genes fail to sort in the internode between speciation events (e.g. Funk \& Omland 2003). This can result in unexpected paraphylies in single locus trees and different topologies of trees inferred from different loci. Incomplete lineage sorting occurs particularly frequently when the effective population size is large and the branch lengths in the phylogenetic tree are short. The effective population size of mtDNA is only a quarter of the effective population size of nuclear genes. Therefore mtDNA is likely to sort faster than nDNA (Avise 2004). Short branch length, however, might be a problem as baboons radiated only 2 mya. Furthermore, incomplete lineage sorting in mtDNA may occur when there is extreme variance in male reproductive success or the absence of female transfer (Hoelzer 1997). Solutions to exclude incomplete lineage sorting are to analyze multiple loci, to use software specialized to detect incomplete lineage sorting (e.g. Hey \& Nielsen 2004) or to check for the random geographic distribution that is expected from incomplete lineage sorting (Avise 2004). In case of baboons I found a clear geographic pattern of every single clade with nearest geographic neighbors clustering together in the phylogenetic tree. 
Furthermore, it remains questionable if the extreme conditions mentioned above (Hoelzer 1997) are met by the genus Papio (Burrell 2008). Incomplete lineage sorting is therefore unlikely to have caused all the mtDNA-morphology discordances in the genus Papio.

A clear geographic pattern with nearest geographic neighbors clustering together in the phylogenetic tree can be an indication for genetic exchange (Funk \& Omland 2003). This leaves introgressive hybridization to be the most likely cause for the discordance between mtDNA clade and morphotype distribution. As I described in the introduction unidirectional gene flow can led to different phylogeographic patterns in mtDNA and nDNA or morphotype. Mitochondrial capture and male introgression are the two possible mechanisms.

As it requires female dispersal mitochondrial capture is no probable explanations for discordances between mtDNA and morphotype distribution in species with predominantly philopatric females. Male biased dispersal and female philopatry is the norm in most mammal species, including Old World primates (Greenwood 1980). In baboons, females are predominantly philopatric as well (Pusey \& Packer 1987) and it can be assumed that this is a plesiomorphic trait. Therefore, I consider it unlikely that female introgression played a significant role in baboon evolution. Mitochondrial capture however may have influenced another species, the Kipunji (Rungwecebus kipunji), a mangabey-like primate from Tanzania (Burrell et al. 2009, Zinner et al. 2009, Roberts et al. 2009). Here yellow baboon mtDNA was integrated into one of the two Kipunji populations. As a result the baboon mtDNA is found in Kipunjis today although the species shows no morphological similarity with yellow baboons. This exiting example is however locally restricted and did not cover the whole Kipunji range (Roberts et al. 2009). Special ecological circumstances like for instance the absence of baboon males in an isolated population might have led to this unexpected scenario. Nevertheless there is no convincing evidence that mitochondrial capture had a significant influence on the phylogenetic history of baboons.

Male introgression seems to be the most likely explanation for the observed discordances between mtDNA clade and morphotype distribution because males are the dispersing sex in baboons and male introgression has already been reported from the hybrid zone between olive and yellow baboons in Kenya (Alberts \& Altmann 2001). If it is indeed the reason for all observed discordances, male introgression has been a driving force during the evolution of the genus Papio.

I will discuss my results in light of the present knowledge of baboon phylogeny starting with the origin of the genus and ending with the current distribution of mtDNA clades and morphotypes. The origin of the genus Papio is one of the less contentious parts of the baboons phylogenetic history. Both, molecular studies (Newman et al. 2004; 
Wildman et al. 2004, Chapter 1 ) as well as the fossil record (Benefit 1999, McKee 1992) came to the conclusion that the genus originates in southern Africa and started to radiate around 2 mya. Earlier Papio fossils were found but their designation to the genus Papio remains questionable and they are not assumed to be ancestors of extant baboons (Gilbert 2008, for a review see Burrell 2008). The question for the ancestor of extant baboons is debated; possible candidates are $P$. robinsoni and $P$. angusticeps, who both lived around the time when the extant baboon's radiation presumably started (Gilbert 2008, for a review see Burrell 2008). The radiation of extant baboons was in temporal accordance with a general trend to drier and cooler climatic conditions in Africa (deMenocal 2004). The subsequent cycles of wet/warm and dry/cool climate (deMenocal 2004) triggered the dispersal of baboon as savannah and open woodland, suitable habitats for baboons (Altmann 1974, Jolly 1993, Kamilar 2006), reacted on the climatic changes with periodic expansions and contractions (Chapter 1, Zinner et al. in press).

The deepest split in the phylogenetic tree of the genus shows a north-south division (Burrell 2008, Chapter 1). As it was pointed out in Chapter 1 an early north-migration of baboons from their southern origin can be assumed (Zinner et al. in press). Savannah corridors in the equatorial forest belt were essential for a north migration of baboons that do not occur in dense rain forests (Kingdon 1997). There is good support for one savannah corridor east of the great African Rift in Tanzania and less support for a second one west of the Rift in the Democratic Republic of Congo (DRC) (Hamilton \& Taylor 1991, Nichol 1999). After the initial north migration the genus populated the northern savannah belt (between the equatorial forest and the Sahara Desert). Most likely populations in northern and southern Africa got separated during times of forest expansions and evolved independently for a while (Zinner et al. in press). Savannah corridors probably opened and closed several times during the glacial and inter-glacial periods in the PlioPleistocene (deMenocal 2004, Hewitt 2000).

Following the rule of parsimony I envision the following migration and gene flow events for southern Africa (Chapter 3). Baboons of the southern lineage diversified into pre-chacma, pre-Kinda and pre-yellow baboons. For Kinda baboons I found no discordances between mtDNA and morphotype in our data set. There is no indication that Kinda baboons hybridized with neighboring populations of yellow and chacma baboons. However, I found Kinda and chacma baboons within few kilometers from each other in Kafue National Park in Zambia. Burrell (2008) failed to detect chacma-Kinda hybrids as well, but in 2009 during ongoing studies mixed troops of Kinda and chacma baboons and intermediate morphotypes were observed by C. Jolly (personal communication). Burrell (2008) found evidence for gene flow between yellow and Kinda baboons though, but the contact zone was not densely sampled. There seems to be a morphological (Frost et al. 2003) and genetic (Burrell 2008) cline between yellow and Kinda baboons. As part of a pre-yellow clade the Luangwa yellow baboons were probably influenced by gene flow 
from Kinda and from northern chacma baboons but retained most of their morphologically yellow features. Nevertheless these baboons have been called dwarf chacmas (P. u. jubilaeus) alternatively (Hill 1970).

The mtDNA I consider to be "original" yellow can be found in four mtDNA clades that cluster together in the phylogenetic tree: Luangwa and southern yellow baboons and northern and eastern chacma baboons. One explanation for the existence of the northern and eastern chacma baboons, which have a chacma morphotype (with some yellow features, Shortridge 1934, Jolly 1993) but carry mitochondria that are closely related to that of yellow baboons (Chapter 3 ), is introgression by chacma males into a yellow or preyellow baboon population. At least today chacma males are bigger than yellow baboon males (Rowe 1996) and might therefore have a selective advantage over them. I assume that pre-chacmas were isolated in South Africa, probably limited by large rivers, such as the Orange and Limpopo River and the Kalahari Desert. Pre-chacmas would then be the direct ancestors of today's Cape chacmas ( $P$. u. ursinus) which are represented in my data set as southern chacma mtDNA clade. Cape chacmas than expanded their range with the expansion of suitable habitat or the disappearance of barriers and met the pre-yellow baboons. As today northern chacma baboons show a morphotype distinct from Cape chacmas, called grayfooted chacma, the hybrid population presumably evolved separately from yellow baboons and Cape chacmas for some time. Today the northern and southern chacma mtDNA clades overlap in northern Namibia and north-eastern South Africa. The third chacma clade I found, the eastern chacmas are so closely related to northern chacmas that they can be considered a subunit of the former.

The southern yellow baboons would consequently constitute a population that has not been affected by introgression events. But that does not mean that southern yellow baboons form a homogenous population. Lake Malawi cuts through their range and separates it in two subclades. Obviously the lake and its southern outlet river acted as part of a dispersal barrier here (Fig. 1 in Chapter 2).

Further to the north the border between the ranges of the major northern and southern mtDNA clades was located in Tanzania. The dense sample collection enabled me to infer on the processes that led to the formation of the border. The present mtDNA border might be the remainder of an ancient species border between yellow baboons in the south and another baboon species, maybe pre-hamadryas baboons in the north. These two species were probably separated by a dispersal barrier. Today the region is continuously occupied by yellow baboons, but the country is crossed by a mountain range and the Ruaha and Rufiji rivers. In combination with the rivers, rain forest on the mountain range might have acted as dispersal barrier during favorable climatic conditions. The tops of the mountain range are still densely forested and yellow baboons normally do not cross dense rain forest (Kingdon 1997). 
North of this border we find a large mtDNA clade that includes northern and coastal yellow baboons, eastern olive and hamadryas baboons (Chapter 1, 2). The mtDNA phylogeny of northern African baboons has been discussed intensively by Zinner et al. (in press). Following his inferences the most parsimonious explanation for the close relatedness of these different species on the mitochondrial level seems to be that their mitochondria are all descendants from pre-hamadryas baboons that were introgressed by yellow baboons from the south and olive baboons from the west. This leaves the question for the "original" olive baboon mitochondria. If eastern olive baboons carry hamadryas or pre-hamadryas mtDNA than either one of the two olive baboon clades we found in western Africa are possible candidates, at least among the clades detected so far. Both of these clades for which only very few samples are available are, on the mitochondrial level, related to Guinea baboons but form well supported monophyletic groups. It cannot be said at the moment if one of these clades contains the "original" olive mtDNA or if it just has not been found yet. Given the scarcity of samples from northern sub-Saharan Africa the latter is not unlikely. The Guinea baboons seem to form a monophyletic group, but again samples from crucial areas are missing and hybridization between olive and Guinea baboons seems very likely along their contact zone. What can be suggested from the available data, however, is that olive baboons seem to be very successful introgressors, who introgressed at least yellow and hamadryas baboons and most likely replaced them in parts of their former range (Zinner et al. in press). If the two western olive mtDNA clades do not contain the "original" olive mtDNA they might even be relicts of populations whose morphotype is extinct nowadays after complete nuclear swamping (also called cytonuclear extinction) by olive baboon males. This olive baboon introgression can still be observed in Amboseli (Tung et al. 2008).

The phylogenetic history of baboons does not only represent a very interesting example for the phylogenetic history of a diverse genus that spread over an entire continent and maintained morphological entities despite hybridization. The evolutionary history of baboons is also a piece in the puzzle of the continents natural history. Baboons have been influenced by the same biogeographic and climatic events that shaped many other species' histories. Especially contemporaneous mammal taxa, which prefer similar habitats, share parts of their history with the genus Papio. Like baboons a southern African origin has been proposed for lions (Panthera leo) (Barnett et al. 2006), kudus (Tragelaphus strepsiceros) (Grau Nersting \& Arctander 2001), and wildebeests (Connochaetes taurinus) (Arctander et al. 1999). An early north-south division can be found in many ungulates (giraffe (Giraffa camelopardalis): Brown et al. 2007, warthog (Phacochoerus africanus): Muwanika et al. 2003, hartebeest (Alcelaphus buselaphus): Flagstad et al. 2001, wildebeest (C. taurinus): Arctander et al. 1999, and roan antelope (Hippotragus equinus): Alpers et al. 2004) and spotted hyenas (Crocuta crocuta) (Rohland et al. 2005). Like in baboons, a complicated mosaic of taxa in East Africa can be found in 
eland antelopes (Taurotragus oryx) (Lorenzen et al. 2010) and giraffes (G. camelopardalis) (Brown et al. 2007) as well.

One possible explanation for the present distribution of taxa is the historic distribution pattern of suitable habitats, in this case savannahs and open woodlands. The southern origin of several taxa might have been caused by a southern savannah refuge in which savannah species evolved and survived during forest expansions and spread again thereafter. Additionally, the existence of several taxa of baboons, giraffes and eland antelopes in east Africa suggests multiple refugia in eastern Africa during unfavorable climatic conditions. A northern refuge in which the northern lineages of several savannah species survived is also likely. Such inferences about probable refugia may also be relevant for questions concerning our own ancestors, who might have used the same refugia. As large omnivore primates, baboons shared body size and habitat preferences with early hominins. Baboon phylogeography might therefore be an analogous model for hominin history (e.g. Strait \& Wood 1999). Based on fossil records, Gilbert (2008) found that hominin and papionin dispersal events are closely linked during the Plio-Pleistocene. Probably the taxa are united by their ecological plasticity (Gilbert 2008) which made both of them so successful.

In general, baboons can definitely be considered a successful taxon. They are spread over most parts of the African continent and adapted to a variety of different habitats. In many places they even learned how to take advantage of human induced changes in their habitat (own observations). Nevertheless conservation issues are of growing importance for baboons as well. As my study showed the genus is subdivided into many genetic subunits at least on the mitochondrial level. Some of these subunits have a restricted geographic range and deserve protection. The Kinda baboons form an evolutionary significant unit. Their range is restricted to Angola, Zambia and southeastern DRC and while we know that they are rarely found outside national parks in Zambia (own observations), we have no knowledge about their status in Angola and DRC. Their range and population size in these areas is not known. I assume however that baboons in Angola and DRC are under very high hunting pressure due to the politically unstable situation and following poverty. Therefore it is of great importance to underline the evolutionary significance and genetic distinctiveness of the Kinda baboon. Another Zambian taxon that deserves protection is the Luangwa yellow baboon which only occurs along the lower Luangwa River. Fortunately, their relatively small range is already protected by three national parks. For western Africa where samples are scarce so far I can only speculate. Several subspecies of the olive baboon have been described but were lumped together afterwards (Hill 1970 and references therein). Detailed analyses of genetic and morphological traits would probably reveal several subunits, which might be under threat. The greatest obstacles to baboon conservation are the public opinion that they are not endangered and their designation as a "pest species". The IUCN red list gives 
yellow, hamadryas, chacma and olive baboons the status "least concern". Only the Guinea baboon is considered to be "near threatened" and Kinda baboons are not listed at all (IUCN 2009). These designations might be true for parts of the respective species range but not species wide. A change in mind towards realizing that not all baboons, not even within one species, are the same is desirable.

The question of conservation raises the question of taxonomy as species and subspecies are often considered to deserve more protection than other genetic units. Baboon taxonomy has been called one of the most contentious issues in primatology (Groves 2001, Kamilar 2006). In my opinion conservation cannot afford to let the taxonomic debate hamper its efforts. As I stated earlier I consider the six main morphotypes of the genus Papio to be species. The definition of these species by their morphology is clearly unsatisfying but I consider it to be the most sensible way given the absence of sufficient nuclear genetic data.

MtDNA is definitely not suitable to define baboon species and maybe not suitable to define any species with a strong male biased dispersal if gene flow between species is possible. The mating system of a species strongly influences the frequency of gene flow in maternal, paternal and biparental markers. A general species definition by the genetic distances between maternal markers seems not sensible for social, bisexual organisms if there is gene flow between species.

Without nuclear genetic data a clear species designation stays difficult and so stays the exact analysis of ancient and contemporary hybridization in baboons. Using mtDNA and additional morphological information this study allowed inferences about ancient hybridization and I was able to generate reasonable explanations for regional patterns of discordances between the ranges of mtDNA clades and morphotypes, namely male introgression. Still, this explanation remains speculative without evidence from nuclear genetic data. An analysis of the phylogeny of maternal, paternal and biparental markers would allow a direct comparison of sex-specific gene flow between species. Especially, the contact and/or overlapping zones between mtDNA clades of the same or similar morphotype can only be located using mtDNA, but further questions for the direction of gene flow cannot be answered.

Furthermore, even the mtDNA data set is far from being complete. My study focused on southern Africa where most of the baboons range could be sampled, but even here some areas are missing from the data set. Especially, the species border between Kinda and chacma baboons in Angola and the border between yellow and chacma baboons in Mozambique remain to be sampled. Furthermore my sample set did not allow conclusions on the existence of the Ruacana-chacma subspecies that is supposed to occupy northern Namibia and Angola. In western and central Africa wide areas of the northern savannah belt have not been studied which includes the supposed hybrid zone 
between olive and Guinea baboons. Therefore the history of olive baboons can only be guessed on so far.

\section{Outlook}

Two important things remain to be done to complete our understanding of baboon phylogeny. The first one is to complete the sample collection by acquiring samples from so far unsampled regions with a focus on contact zones between taxa. The second is to use a completed sample set for analyses of paternal and biparental markers. Population genetics of all species would allow exiting possibilities for species comparisons. The comparison of pure and hybrid populations promises most interesting inferences about hybridization mechanisms.

Some specific tasks directly arise from this study. In western Africa more samples from the supposed hybrid zone between Guinea and olive baboons will answer the question if the two species truly interbreed in the wild. Nuclear genetic markers would also reveal the direction of gene flow. Furthermore, the identification of the "original" olive baboon mtDNA would shed light on the history of olive baboons, the species with the largest range of all baboon species. In southern Africa the species borders in Angola (chacma-Kinda) and central Mozambique (chacma-yellow) remain to be sampled. Similarly the possible existence of Ruacana chacma baboons in Angola and northern Namibia can only be proved with more samples, especially from their type location. I sampled the border between the ranges of the northern and southern yellow baboon mtDNA-clades and the northern and southern chacma mtDNA clades and could infer on possible ancient hybridization events, but the investigation of direction and patterns of recent gene flow requires the analysis of nDNA.

\section{Conclusions}

Drawing a detailed picture of the current geographic distribution of baboon mtDNA clades and comparing these to morphotype distributions, my studies revealed that male introgression and subsequent nuclear swamping is most likely an important mechanism in baboon evolution. It has the potential to explain all discordances that I found between the contemporary distributions of mtDNA clades and morphotypes. My phylogenetic analyses allowed me to describe a likely history of the genus Papio from its origin to its present distribution. The inferred phylogenetic history was most likely triggered by climatic changes that affected the expansion and retraction of suitable habitat for baboons. By means of baboon phylogeny mtDNA showed its potential to expose ancient population structures in female philopatric species. At the same time my study elucidated the limits of mtDNA phylogenies and underlines the need for the use of multiple markers to answer phylogenetic as well as taxonomic questions. 


\section{References}

Alberts SC, Altmann J: Immigration and hybridization patterns of yellow and anubis baboons in and around Amboseli, Kenya. American Journal of Primatology 2001, 53(4):139-154.

Alpers D, Van Vuuren B, Arctander P, Robinson T: Population genetics of the roan antelope (Hippotragus equinus) with suggestions for conservation. Molecular Ecology 2004, 13:1771-1784.

Altmann S: Baboons, Space, Time, and Energy. American Zoologist 1974, 14(1):221-248.

Arctander P, Johansen C, Coutellec-Vreto MA: Phylogeography of three closely related African bovids (tribe Alcelaphini). Molecular Biology and Evolution 1999, 16(12):1724-1739.

Avise J: Phylogeography: the history and formation of species. Cambridge: Harvard University Press; 2000.

Avise J: Molecular Markers, Natural History, and Evolution. Sunderland, MA: Sinauer Associates; 2004.

Barrett L: A Guide to Practical Babooning: Historical, Social, and Cognitive Contingency. Evolutionary Anthropology 2009, 18:91-102.

Barrett L, Henzi P: The social nature of primate cognition. Proceedings of the Royal Society B 2005, 272:1865-1875.

Barnett R, Yamaguchi N, Barnes I, Cooper A: The origin, current diversity and future conservation of the modern lion (Panthera leo). Proceedings of the Royal Society B 2006, 273(1598):2119-2125.

Benefit B: Biogeography, dietary specialization, and the diversification of African pliopleistocene monkeys. In: African Biogeography, Climate Change, \& Human Evolution. Edited by Bromage T, Schrenk F. Oxford; 1999: 172-188.

Bergman TJ, Beehner JC: Social System of a Hybrid Baboon Group (Papio anubis $\times \boldsymbol{P}$. hamadryas). International Journal of Primatology 2004, 25(6):1313-1330.

Bonhomme M, Cuartero S, Blancher A, Crouau-Roy B: Assessing natural introgression in 2 biomedical model species, the Rhesus macaque (Macaca mulatta) and the longtailed macacque (Macaca fascicularis). Journal of Heredity 2009, 100(2):158-169. 
Brown D, Brenneman R, Koepfli K-P, Pollinger J, Mila B, Georgiadis N, Louis E, Grether G, Jacobs $D$, Wayne R: Extensive population genetic structure in the giraffe. $B M C$ Evolutionary Biology 2007, 5(1):57.

Burrell A, Jolly C, Tosi A, Todd R, Disotell T: Mitochondrial evidence for the hybrid origin of the kipunji, Rungwecebus kipunji (Primates: Papionini). Molecular Phylogenetics and Evolution 2009.

Burrell AS: Phylogenetics and population genetics of central African baboons. PhD thesis. New York: New York University; 2008.

Centron D, Ramirez B, Fasola L, Macdonald D, Chehebar C, Schiavini A, Cassini M: Diversity of mtDNA in Southern River Otter (Lontra provocax) from Argentinean Patagonia. Journal of Heredity 2008, 99(2):198-201.

Cheney D, Seyfarth R: Baboon Metaphysics. Chicago and London: Chicago University Press; 2007.

Cracraft J: Species concepts and speciation analysis. In: Current Ornithology. Edited by Johnston R. New York: Plenum Press; 1983: 159-187.

Cronin J, Sarich V: Molecular evidence for the dual origin of the mangabeys among Old World monkeys. Nature 1976, 260:700-702.

Cronquist A: Once again, what is a species? In: Biosystematics in agriculture. Edited by Ramberger J. Monclair (NJ): Allanheld \& Osmun; 1978: 3-20.

deMenocal PB: African climate change and faunal evolution during the PliocenePleistocene. Earth and Planetary Science Letters 2004, 220(1-2):3-24.

de Queiroz K, Donoghue M: Phylogenetic systematics and the species problem. Cladistics 1988, 4:317-338.

Disotell T: Generic level relationships of the papionini (Cercopithecoidea). American Journal of Physical Anthropology 1994, 94(1):47-57.

Disotell T: Molecular evolution of the Papionini (Primates: Cercopithecinae). PhD thesis. Cambridge: Harvard University; 1992.

Dobzhansky T: Genetics and the Origin of Species. New York: Columbia University Press; 1937.

Dunbar R: Ecological constraints on group size in baboons. In: Animal Societies: Individuals, Interactions and Social Organisation. Edited by Jarman P, Rossiter A. Oxford: Blackwell; 1994: 221-236. 
Flagstad $\mathrm{O}$, Syvertsen $\mathrm{P}$, Stenseth $\mathrm{N}$, Jakobsen $\mathrm{K}$ : Environmental change and rates of evolution: the complex phylogeographic pattern within the hartebeest complex as related to climatic variation. Proceedings of the Royal Society $B$ 2001, 268:667677.

Frost S, Marcus L, Bookstein F, Reddy D, Delson E: Cranial allometry, phylogeography, and systematics of large-bodied Papionins (Primates: Cercopithecus) inferred from geometric morphometric analysis of landmark data. The anatomical record part A 2003, 275(A):1048-1072.

Funk D, Omland K: Species-Level Paraphyly and Polyphyly: Frequency, Causes, and Consequences, with Insights from Animal Mitochondrial DNA. Annual Review of Ecology, Evolution, and Systematics 2003, 34:397-423.

Futuyama D: Evolution. Sunderland: Sinauer Associates, Inc.; 2005.

Galat-Luong A, Galat G, Hagell S: The social and ecological flexibility of Guinea baboons: implications for Guinea baboons social organization and male strategies. In: Reproduction and Fitness in Baboons Behavioral, Ecological, and Life History Perspectives. Edited by Swedell L, Leigh S. New York: Springer; 2006: 105-121.

Geissmann T: Vergleichende Primatologie. Berlin Heidelberg: Springer; 2003.

Gilbert C: African Papionin Phylogenetic History and Plio-Pleistocene Biogeography. PhD thesis. New York: Stony Brook University; 2008.

Gilbert C: Craniomandibular morphology supporting the diphyletic origin of mangabeys and a new genus of the Cercocebus/Mandrillus clade, Procercocebus. Journal of Human Evolution 2007, 53(1): 69-102.

Grau Nersting L, Arctander P: Phylogeography and conservation of impala and greater kudu. Molecular Ecology 2001, 10(3):711-719.

Greenwood P: Mating system, philopatry and dispersal in birds and mammals. Animal Behaviour 1980, 28:1140-1162.

Groves C: Primate Taxonomy. Washington DC: Smithsonian Institution Press; 2001.

Groves C: Phylogenetic and populations systematics of the mangabeys (Primates: Cercopithecoidea). Primates 1978, 19:1-34.

Grubb P: Assessment of the diversity of african primates. International Journal of Primatology 2003, 24(6):1301-1357.

Hamilton A, Taylor D: History of climate and forests in tropical Africa during the last 8 million years. Climatic Change 1991, 19:65-78. 
Hapke A, Zinner D, Zischler $\mathrm{H}$ : Mitochondrial DNA variation in Eritrean hamadryas baboons (Papio hamadryas hamadryas): life history influences population genetic structure. Behavioural Ecology and Sociobiology 2001, 50:483-492.

Hewitt G: The genetic legacy of the Quaternary ice ages. Nature 2000, 405:907-913.

Hey J, Nielsen R: Multilocus methods for estimating population sizes, migration rates and divergence time, with applications to the divergence of Drosophila pseudoobscura and D. persimilis. Genetics 2004, 167:747-760.

Hill R, Dunbar R: Climatic determinants of diet and foraging behaviour in baboons. Evolutionary Ecology 2002, 16:579-593.

Hill R, Lycett J, Dunbar R: Ecological and social determinants of birth intervals in baboons. Behavioral Ecology 2000, 11(5):560-564.

Hill W: Primates comparative anatomy and taxonomy, vol. 8 Cynopithecinae. Edinburgh: Edinburgh University Press; 1970.

Hoelzer G: Inferring phylogenies from mtDNA variation: mitochondrial-gene trees versus nuclear-gene trees revisited. Evolution 1997, 51(2):622-626.

IUCN 2009. IUCN Red List of Threatened Species. Version 2009.2. www.iucnredlist.org

Jolly C: A proper study for mankind: Analogies from the Papionin monkeys and their implications for human evolution. Yearbook of Physical Anthropology 2001, 44:177-204.

Jolly, C: Baboon nomenclature. African Primates 1997-1998, 3: 47-48.

Jolly C: Species, subspecies and baboon systematics. In: Species, Species Concepts, and Primate Evolution. Edited by Kimbel W, Martin L. New York: Plenum Press; 1993: 67-107.

Jolly C: The origin and Specialisations of the Long-Faced Cercopithecoidea. PhD thesis. London: University of London; 1965.

Jolly C, Phillips-Conroy J: "White babies" and the zone of contact and probable intergradation among three distinct baboon allotaxa in the Luangwa valley, Zambia. American Journal of Physical Anthropology 2005, Suppl. 40:123.

Kappeler $\mathrm{P}$, van Schaik C: Evolution of primate social systems. International Journal of Primatology 2002, 23:707-740. 
Kamilar J: Geographic variaiton in savanna baboon (Papio) ecology and its taxonomic and evolutionary implications. In: Primate Biogeography Progress and Prospects. Edited by Lehman S, Fleagle J. New York: Springer; 2006: 169-200.

Kingdon J: The Kingdon field guide to African mammals. London: Academic Press; 1997.

Kingston S, Adams L, Rosel P: Testing mitochondrial sequences and anonymous nuclear markers for phylogeny reconstruction in a rapidly radiating group: molecular systematics of the Delphininae (Cetacea: Odontoceti: Delphinidae). BMC Evolutionary Biology 2009, 9(245).

Kuhn H: Zur Systematik der Cercopithecidae. In: Neue Ergebnisse der Primatologie. Edited by Starck D, Schneider R, Kuhn H. Stuttgart: G. Fischer; 1967: 25-46.

Lorenzen E, Masembe C, Arctander P, Siegismund H: A long-standing Pleistocene refugium in southern Africa and a mosaic of refugia in East Africa: insights from mtDNA and the common eland antelope. Journal of Biogeography 2010, 37:571581.

Mayr E: Principles of systematic zoology. Cambridge (MA): Harvard University Press; 1969.

McKee J: The southern African origin of the genus Papio. South African Journal of Medicine 1992, 82:193.

Muwanika VB, Nyakaana S, Siegismund HR, Arctander P: Phylogeography and population structure of the common warthog (Phacochoerus africanus) inferred from variation in mitochondrial DNA sequences and microsatellite loci. Heredity 2003, 91(4):361-372.

Nagel U: A comparison of anubis baboons, hamadryas baboons and their hybrids at a species border in Ethiopia. Folia Primatologica 1973, 19:104-165.

Newman T, Jolly C, Rogers J: Mitochondrial phylogeny and systematics of baboons (Papio). American Journal of Physical Anthropology 2004, 124:17-27.

Nichol J: Geomorphological evidence and Pleistocene refugia in Africa. The Geographical Journal 1999, 165:79-89.

Nystrom P: Mating success of hamadryas, anubis, and hybrid male baboons in a "mixed" social group in the Awash National Park, Ethiopia. PhD thesis. Washington Washington University; 1992.

Phillips-Conroy JE: Genetic and behavioral observations of "Kinda" baboons (Papio cynocephalus kindae) in Zambia. American Journal of Physical Anthropology 2009, Suppl. 48:211. 
Phillips-Conroy J, Jolly C: Changes in the structure of the baboon hybrid zone in the Awash National Park, Ethiopia. American Journal of Physical Anthropology 1986, 71:337-350.

Pusey A, Packer C: Dispersal and philopatry. In: Primate Societies. Edited by Smuts B, Cheney D, Seyfarth R, Wrangham R, Struhsaker T. Chicago: The University of Chicago Press; 1987: 250-266.

Roberts T, Davenport T, Hildebrandt K, Jones T, Stanley W, Sargis E, Olson L: The biogeography of introgression in the critically endangered African monkey Rungwecebus kipunji. Biology Letters 2009, published online.

Rohland N, Pollack J, Nagel D, Beauval C, Airvaux J, Pääbo S, Hofreiter M: The Population History of Extant and Extinct Hyenas. Molecular Biology and Evolution 2005, 22(12):2435-2443.

Roos C, Nadler T, Walter L: Mitochondrial phylogeny, taxonomy and biogeography of the silvered langur species group (Trachypithecus cristatus). Molecular Phylogenetics and Evolution 2008, 47:629-636.

Rowe N: The pictorial guide to the living primates. East Hampton, NY: Pogonias Press; 1996.

Samuels A, Altmann J: Immigration of a Papio anubis male into a groupp of Papio cynocephalus baboons and evidence for an anubis-cynocephalus hybrid zone in Amboseli, Kenya. International Journal of Primatology 1986, 7(2):131-138.

Shortridge G: The Mammals of South West Africa, vol. 1. London: Heinemann; 1934.

Simpson G: Principles of animal taxonomy. New York: Columbia University Press; 1961.

Smuts B, Cheney D, Seyfarth R, Wrangham R: Primate Societies. Chicago University of Chicago Press; 1987.

Spinks $P$, Thomson $R$, Lovely $G$, Shaffer $H$ : Assessing what is needed to resolve a molecular phylogeny: simulations and empirical data from emydid turtles. $B M C$ Evolutionary Biology 2009, 9(56).

Strait D, Wood B: Early hominid biogeography. Proceedings of the National Academy of Science USA 1999, 96(16):9196-9200.

Szalay F, Delson E: Evolutionary history of the primates. New York: Academic Press; 1979. 
Tahiri-Zagrët C: Les cercopithecidae de Côte d'Ivoire. Bulletin de I'IFAN Ser A 1976, 38:206-230.

Thalmann O, Hebler J, Poinar H, Paabo S, Vigilant L: Unreliable mtDNA data due to nuclear insertions: a cautionary tale from analysis of humans and other great apes. Molecular Ecology 2004, 13(2):321-335.

Tosi A, Morales J, Melnick D: Paternal, maternal, and biparental molecular markers proviede unique windows onto the evolutionary history of macaque monkeys. Evolution 2003, 57(6):1419-1435.

Tung J, Charpentier M, Garfield DA, Altmann J, Alberts S: Genetic evidence reveals temporal change in hybridization patterns in a wild baboon population. Molecular Ecology 2008, 17(8):1998-2011.

VandeBerg J, Cheng $\mathrm{M}$ : The genetics of baboons in biomedical research. In: Primate Evolutiom. Edited by Else J, Le P. Cambridge: Cambridge University Press; 1986: 316-327.

Van Ngoc T: Phylogeny of Gibbons (family Hylobatidae) with Focus on Crested Gibbon (genus Nomascus). PhD thesis. Goettingen: Georg-August-University Goettingen; 2010.

Van Valen L: Ecological species, multispecies, and oaks. Taxon 1976, 25:233-239.

Waser P: The evolution of male loud calls aming mangabeys and baboons. In: Primate Communication. Edited by Snowdon C, Brown C, Petersen M. Cambridge: Cambridge University Press; 1982.

Wildman D, Bergman T, al-Aghbari A, Sterner K, Newman T, Phillips-Conroy J, Jolly C, Disotell T: Mitochondrial evidence for the origin of hamadryas baboons. Molecular Phylogenetics and Evolution 2004, 32(1):287-296.

Williams-Blangero S, Vandeberg J, Blangero J, Konigsberg L: Genetic Differentiation between baboon subspecies: relevance for biomedical research. American Journal of Primatology 1990, 20:67-81.

Winney B, Hammond R, Macasero W, Flores B, Boug A, Biquand V, Biquand S, Bruford M: Crossing the red sea: phylogeography of the hamadryas baboon Papio hamadryas hamadryas. Molecular Ecology 2004, 13:2819-2827.

Woolley-Barker T: Social organization and genetic structure in a baboon hybridzone. PhD thesis. New York: New York University; 1999.

Zinner D, Umaru B, Nash S, Roos C: Pan-African Voyagers. The Phylogeography Of Baboons. In: Primates of Gashaka Socio-ecology and Conservation in Nigeria's 
Biodiversity Hotspot Series: Developments in Primatology: Progress and Prospects. Edited by Sommer V, Ross C. New York: Springer; in press.

Zinner D, Arnold M, Roos C: Is the New Primate Genus Rungwecebus a Baboon? PLoS ONE 2009, 4(3): e4859. 


\section{Curriculum Vitae}

\author{
Christina Keller \\ 22.05.1981 \\ Muenster, Germany \\ German
}

PhD-student in Cognitive Ethology Lab at the German Primate Centre, and the Göttingen Centre for Biodiversity and Ecology, University of Goettingen, Germany. Advisors: Prof. Dr. Julia Fischer

Dr. Dietmar Zinner Dr. Christian Roos Prof. Dr. Peter Kappeler Prof. Dr. Eckhard Heymann

$$
\text { Diploma thesis }
$$

Title: Do small mammals affect plant diversity? Advisors: Prof. Dr. Norbert Sachser

Dr. Carsten Schradin

Study of Biology at the University of Muenster

\section{Bibliographic Information}

Name

Date of Birth

Place of birth

Citizenship

\section{Education}

Since 01.01.2007 


\section{PUBLICATIONS}

Keller C, Roos C, Zinner D. (in prep). Phylogeography of yellow baboons (Papio cynocephalus) in East Africa: evaluation of a mitochondrial border

Meise K, Fischer J, Keller C, Cowlishaw G (submitted to JASA)

Sources of acoustic variation: implications for production specificity and call categorization in chacma baboon grunts.

Keller C, Roos C, Zinner D (2010) Introgressive hybridization in southern African baboons shapes patterns of mtDNA variation. American Journal of Physical Anthropology 142: 125-136.

Zinner D, Groeneveld LF, Keller C, Roos C (2009) Mitochondrial phylogeography of baboons (Papio spp.) - Indication for introgressive hybridization? BMC Evolutionary Biology 9:83.

Keller C, Schradin C (2008) Plant and small mammal diversity correlate positively in a biodiversity hotspot. Biodiversity \& Conservation 17 (4): 911-923.

Schradin C, Krackow S, Schubert M, Keller C, Schradin B, Pillay N (2007). Regulation of activity in desert-living striped mice: the importance of basking. Ethology 11: 606-614. 


\section{Acknowledgements}

First of all I want to thank Julia Fischer for her supervision, for her believe in me and my project and for setting an excellent example on how to be a scientist. My greatest thanks go to Dietmar Zinner for sharing his expertise on baboon phylogeny, for his open door, whenever I needed his help and especially for his unfailing patience in numerous difficult discussions. For his support in the lab, useful discussions and his help with getting the whole project started I thank Christian Roos. Invaluable practical help in the lab came from Christiane Schwarz and Christina Oberdiek. My field work would not have been possible without the help of Kristine Meise (Namibia), Markus Metz (Zambia), Julius W. Nyahongo (Tanzania) and Dana Pfefferle (South Africa). Thanks to all of you for great times, for thousands of memorable kilometers on African roads and lots of samples. For helping to organize my work in Namibia I thank Guy Cowlishaw. For tracking a lost parcel full of baboon pooh, finding it in a Backpacker and managing to send it to Germany after weeks of sleepless nights I thank FedEx in Cape Town. Statistical support came from Linn F. Groeneveld and Matthias Markolf. I thank Eckhard Heymann for evaluating this thesis. Peter Kappeler and Claudia Fichtel owe my thanks for organizing the Primate-DiversityProject at the DPZ. Financial support came from the WGL, the Christian-Vogel-Fond and the DPZ, which was an excellent place to work. For their help with organization from the DPZ I thank Ellen Wiese, Nadine Ellrott and Heike Klensang.

I also like to thank my whole working group Cognitve Ethology for discussions, for social support, many cups of coffee and much more. Especially I want to thank Dana for her uncounted advises, for enlightening discussions after hours in the office and just for being there. To thank Gisela for listening to my loud thoughts during the final stage of the thesis and for keeping me from working when I needed a break, I will cite her favorite sentence that unfortunately did not make it into the final version of the thesis. "A dense sampling over the range of olive and Guinea baboons promises exiting insights into the history of these species that we only had a glimpse of so far."

My family in Greven was an ever present source of encouraging words and provided a place to relax and rest whenever I needed it. I also wish to thank Ruben and especially Jörg for telling me when it is time to accept things that I cannot change, when it is time to change things I can change and when enough is enough. Last but not least I thank Heiko for keeping my work from being the centre of my life. 


\section{Erklärung}

Hiermit versichere ich, dass ich die vorliegende Arbeit selbständig verfasst und keine anderen als die angegebenen Quellen und Hilfsmittel benutzt habe. Desweiteren erkläre ich, dass ich mich nicht anderweitig einer Doktorarbeit ohne Erfolg unterzogen habe und dass diese Arbeit in gleicher oder ähnlicher Form noch keiner anderen Prüfungsbehörde vorgelegen hat.

Die Publikation in Kapitel 1 wurde von D. Zinner verfasst. Ich leistete bei der Sammlung der Proben sowie bei der Verfassung des Manuskriptes einen wesentlichen Beitrag. Das unveröffentlichte Manuskript in Kapitel 2 sowie die Publikation in Kapiteln 3 wurden von mir selbst verfasst. Alle Koautoren wirkten bei der Finalisierung der Manuskripte mit.

Göttingen, den ～März 2010

Christina Keller 